\title{
Sediment and carbon accumulation in a glacial lake in Chukotka (Arctic Siberia) during the Late Pleistocene and Holocene: combining hydroacoustic profiling and down-core analyses
}

\author{
Stuart A. Vyse ${ }^{1,2}$, Ulrike Herzschuh ${ }^{1,2,4}$, Gregor Pfalz ${ }^{1,3}$, Lyudmila A. Pestryakova ${ }^{5}$, Bernhard Diekmann ${ }^{1,2,3}$, \\ Norbert Nowaczyk ${ }^{6}$, and Boris K. Biskaborn ${ }^{1}$ \\ ${ }^{1}$ Alfred Wegener Institute Helmholtz Centre for Polar and Marine Research, Research Unit Potsdam, \\ Telegrafenberg A45, 14471 Potsdam, Germany \\ ${ }^{2}$ Institute of Environmental Science and Geography, University of Potsdam, Potsdam, Germany \\ ${ }^{3}$ Institute of Geosciences, University of Potsdam, Potsdam, Germany \\ ${ }^{4}$ Institute of Biochemistry and Biology, University of Potsdam, Potsdam, Germany \\ ${ }^{5}$ Northeastern Federal University of Yakutsk, Department for Geography and Biology, Yakutsk, Russia \\ ${ }^{6}$ Helmholtz Centre Potsdam GFZ, Climate Dynamics and Landscape Evolution, \\ Telegrafenberg, 14473 Potsdam, Germany
}

Correspondence: Stuart A. Vyse (stuart.vyse@awi.de) and Boris K. Biskaborn (boris.biskaborn@awi.de)

Received: 16 February 2021 - Discussion started: 22 February 2021

Revised: 2 July 2021 - Accepted: 8 July 2021 - Published: 24 August 2021

\begin{abstract}
Lakes act as important sinks for inorganic and organic sediment components. However, investigations of sedimentary carbon budgets within glacial lakes are currently absent from Arctic Siberia. The aim of this paper is to provide the first reconstruction of accumulation rates, sediment and carbon budgets from a lacustrine sediment core from Lake Rauchuagytgyn, Chukotka (Arctic Siberia). We combined multiple sediment biogeochemical and sedimentological parameters from a radiocarbon-dated $6.5 \mathrm{~m}$ sediment core with lake basin hydroacoustic data to derive sediment stratigraphy, sediment volumes and infill budgets. Our results distinguished three principal sediment and carbon accumulation regimes that could be identified across all measured environmental proxies including early Marine Isotope Stage 2 (MIS2) (ca. 29-23.4 ka cal BP), mid-MIS2early MIS1 (ca. 23.4-11.69 ka cal BP) and the Holocene (ca. 11.69-present). Estimated organic carbon accumulation rates (OCARs) were higher within Holocene sediments (average $3.53 \mathrm{~g} \mathrm{OC} \mathrm{m}^{-2} \mathrm{a}^{-1}$ ) than Pleistocene sediments (average $1.08 \mathrm{~g} \mathrm{OC} \mathrm{m}^{-2} \mathrm{a}^{-1}$ ) and are similar to those calculated for boreal lakes from Quebec and Finland and Lake Baikal but significantly lower than Siberian thermokarst lakes and Alberta glacial lakes. Using a bootstrapping approach, we
\end{abstract}

estimated the total organic carbon pool to be $0.26 \pm 0.02 \mathrm{Mt}$ and a total sediment pool of $25.7 \pm 1.71 \mathrm{Mt}$ within a hydroacoustically derived sediment volume of ca. $32990557 \mathrm{~m}^{3}$. The total organic carbon pool is substantially smaller than Alaskan yedoma, thermokarst lake sediments and Alberta glacial lakes but shares similarities with Finnish boreal lakes. Temporal variability in sediment and carbon accumulation dynamics at Lake Rauchuagytgyn is controlled predominantly by palaeoclimate variation that regulates lake icecover dynamics and catchment glacial, fluvial and permafrost processes through time. These processes, in turn, affect catchment and within-lake primary productivity as well as catchment soil development. Spatial differences compared to other lake systems at a trans-regional scale likely relate to the high-latitude, mountainous location of Lake Rauchuagytgyn.

\section{Introduction}

Lakes represent key sentinels of environmental change and can respond rapidly to changes in environmental conditions (Adrian et al., 2009). Lakes act as sinks of clastic sediment derived from local catchment weathering processes as well as 
from atmospheric deposition and as such gradually accumulate sediment mass over time (Dietze et al., 2014; Hinderer and Einsele, 2001). They also constitute a significant net sink of carbon, as they can accumulate organic and inorganic carbon within their sediments derived from allochthonous (lake external) and autochthonous (lake internal) pathways (Ferland et al., 2012; Dean and Gorham 1998; Kortelainen et al., 2004; Sobek et al., 2014). Recent syntheses suggest that global lakes represent a carbon sink of around 0.2$0.6 \mathrm{Pg} \mathrm{C} \mathrm{yr}^{-1}$ (Cole et al., 2007; Battin et al., 2009). In turn, inland waters can also act as major sources of the greenhouse gases $\mathrm{CO}_{2}$ and $\mathrm{CH}_{4}$ and thereby contribute further to global climate change (Anthony et al., 2014).

Lake sediment cores contain sedimentological and biogeochemical proxies of environmentally driven sedimentation and carbon dynamics (Birks and Birks, 2006; Biskaborn et al., 2019; Smol et al., 2002). When sedimentation rate data are available via dating of sediment cores, estimations of rates of sediment mass and carbon accumulation can be reconstructed (Ferland et al., 2012). Moreover, if the sediment volume stored within a lake basin can be estimated, sediment and carbon pools can be obtained, which allows the lake function as a sediment and carbon sink to be assessed (Campbell et al., 2000; Lehman, 1975; Munroe and Brencher, 2019; Pajunen, 2000).

The region of Chukotka (Arctic Siberia) represents an environmentally sensitive area with limited lacustrine environmental reconstructions (Lozhkin and Anderson, 2013). Though a number of regional records across Arctic Siberia are becoming increasingly prevalent (Biskaborn et al., 2012; Diekmann et al., 2016; Melles et al., 2012; Pfalz et al., 2021; Subetto et al., 2017), studies have often neglected reconstructions of accumulation rates. This is largely due to limited age controls related to problematic radiocarbon dating of organic-poor systems that often lack dateable macrofossil remains and possess low dating resolutions (Lozhkin et al., 2016; Strunk et al., 2020). Current eastern Siberian research has primarily focussed on the reconstruction of Holocene accumulation rates of carbon using sediment cores derived from thermokarst lake systems (Anthony et al., 2014). Such studies have shown that lake systems may operate in transitional modes between carbon sink and source stages depending on the prevailing climatic background conditions (Anthony et al., 2014). Recent syntheses have characterised the sedimentological characteristics and carbon budgets of Bykovsky Peninsula lagoons of northern Yakutia, eastern Siberia, and carbon inventories within alas and yedoma deposits from central Yakutia and are interpreted in terms of palaeoenvironmental variability since the Pleistocene (Jenrich et al., 2021; Windirsch et al., 2020). Such works have also been extended to drained thermokarst lake basins (DTLBs) and Pleistocene yedoma deposits in north-western Alaska (Jongejans et al., 2018). The reconstruction of accumulation rates in these syntheses has, however, been avoided due to significant reworking of carbon material within per- mafrost landscapes (Strunk et al., 2020; Windirsch et al., 2020). The role of Arctic Siberian glacial lakes as sediment and carbon sinks has not yet been accounted for.

Several, broad regional studies of dated sediment cores have been applied in an attempt to calculate accumulation rates and carbon pools within small glacial lakes in the Uinta Mountains, north America (Munroe and Brencher, 2019), as well as in proglacial and bedrock-catchment lakes in southern Greenland (Anderson et al., 2009) and from large glacial lakes in Alberta, Canada (Campbell et al., 2000). A major drawback to these studies, however, is the absence or oversimplification of sediment volume estimation, which does not account for lateral variations in underlying sediment stratigraphy resulting from sediment focussing and winnowing (Ferland et al., 2012). Campbell et al. (2000) suggested an empirical equation for the estimation of sediment volume by simplifying lake sediments to an oblate semi-spheroid to account for sediment thinning at the lake margins. However, such approaches have been shown to lead to significant overestimations of sediment volumes and carbon pools up to 4 times the true value (Ferland et al., 2012; Munroe and Brencher, 2019). Hence the lack of efficient derivation of sediment volumes represents a major disadvantage of current works. Recent studies that include seismic- or hydroacoustic-based appraisals of sediment volume account for these disadvantages and show a major improvement of pool calculations (Einola et al., 2011; Ferland et al., 2012; Pajunen et al., 2000). Such methods are simple, rapid and give significant additional insight into lake bathymetry and basin-wide sediment stratigraphy that permits the retrieval of sediment thicknesses and volumes (Ferland et al., 2012). Recent hydroacoustic-based studies from central and western Siberia have concentrated on determining Holocene and Late Pleistocene sediment distributions and volumes within glacial lakes and have proven highly useful for understanding glacial history in these regions (Haflidason et al., 2019; Lebas et al., 2019). The inclusion of sediment budgets within investigations of carbon pools is important as it allows the future storage capacity of lakes to be estimated (Hinderer and Einsele, 2001).

This paper aims to provide a first estimation of Late Pleistocene-Holocene sediment and carbon accumulation within an Arctic glacial lake basin within the remote Chukotka region (Arctic Siberia). This includes the first reconstruction of Pleistocene-Holocene sediment and organic carbon accumulation rates and pools provided for Chukotka derived by integrating proxy analyses from a high-resolution dated sediment core with high-resolution hydroacoustic data for sediment volumes. Our results are interpreted in the context of regional palaeoenvironmental variability during the Late Pleistocene and are compared to trans-regional studies from Yakutia (east Siberia), North America and Europe. As such, our research questions are the following. 
1. How have the palaeoenvironmental variability in Chukotka and resulting sedimentological processes since Marine Isotope Stage 2 (MIS2) influenced the sediment and carbon accumulation dynamics within an Arctic glacial lake?

2. How much sediment and carbon is stored within the Lake Rauchuagytgyn basin and how is this proportioned between the glacial and interglacial periods?

3. How do accumulation rates compare with other systems at a trans-regional scale?

\section{Study area}

Lake Rauchuagytgyn $\left(67.7922^{\circ} \mathrm{N}, 168.7312^{\circ} \mathrm{E}\right)$ is situated within the glacially eroded U-shaped, Rauchua mountain valley within the north-western Anadyr Mountains of Chukotka (Arctic Siberia), where elevations reach up to $1600 \mathrm{~m}$ a.s.1. (Fig. 1). The lake lies at an elevation of ca. $625 \mathrm{~m}$ a.s.1. with a surface area of ca. $6.1 \mathrm{~km}^{2}$ and maximum water depth of $36 \mathrm{~m}$. The lake is supplied by fluvial inflows at the lakes' southern margin (Rauchua River) and via an alluvial fan at the lakes' south-eastern margin. One major outflow drains the lake to the north, and several minor streams drain the basin sides. The basin is divided into several subregions (southern and south-eastern inflows, southern sub-basin, northern sub-basin and northern shelf) based on water depth characteristics. The catchment area comprises ca. $214.5 \mathrm{~km}^{2}$. The bedrock surrounding the lake and within the catchment is predominantly composed of Cretaceous extrusive and intrusive igneous rocks consisting of silicic-intermediate lithologies dominated by andesite (Zhuravlev and Kazymin, 1999). Catchment evidence for glaciation includes moraines to the north of the lake that denote the maximum extent of glaciation (Glushkova, 2011). Several small glacial cirques are found within the catchment (Glushkova, 2011) (Fig. 1a). The Arctic continental climate of the area is characterised by mean annual temperatures of $-11.8^{\circ} \mathrm{C}$ and average July and January temperatures of 13 and $-30^{\circ} \mathrm{C}$, respectively, with low annual precipitation of ca. $200 \mathrm{~mm}$ (Menne et al., 2012). A surface ice layer is present on lakes in this area from October to early July and likely reaches a winter maximum thickness of ca. $1.8 \mathrm{~m}$ (Nolan et al., 2002). Catchment vegetation is dominated by open herb and graminoid tundra with no vegetation at higher elevations. Some forest tundra is found at lower elevations and adjacent to river valleys (Shevtsova et al., 2020).

\section{Materials and methods}

\subsection{Fieldwork}

Fieldwork took place at Lake Rauchuagytgyn in July 2018. An SES-2000 compact parametric sub-bottom profiler was used to hydroacoustically survey the basin to identify major acoustic units (AUs) and sediment boundaries and to locate an optimal coring location (Innomar Technologies $\mathrm{GmbH}$ ). A low frequency $(8-10 \mathrm{kHz})$ and low pulse interval $(2 \mathrm{~s})$ was used for high sediment penetration to retrieve sediment architecture. A high frequency $(100 \mathrm{kHz})$ and high pulse interval $(253 \mu \mathrm{s})$ allowed derivation of lake bathymetry. Depth conversion was conducted assuming a constant sound velocity of $1500 \mathrm{~m} \mathrm{~s}^{-1}$. In total, 25 hydroacoustic profiles containing $>23000$ data points were retrieved.

Sediment core EN18218 (ca. $653 \mathrm{~cm}$ ) (Fig. 1) was collected from the southern sub-basin using an UWITEC piston coring system. The core was retrieved in parallel overlapping ca. $3 \mathrm{~m}$ segments, cut into $1 \mathrm{~m}$ sections and transported in transparent $60 \mathrm{~mm}$ PVC tubes for further processing. Further core penetration and retrieval was prevented by coarse material comprising of pebble-sized clasts at the core base that most likely represents the lowermost deposited sediments within the basin.

Epilimnetic water samples were collected in 2016 (Huang et al., 2020) and in 2018 (this study) from multiple surface locations and were immediately measured for $\mathrm{pH}$, conductivity and oxygen content (WTW Multilab 540, Germany). Water subsamples were then filtered $(0.45 \mu \mathrm{m})$ and transported for analyses of dissolved organic carbon (DOC), anions and cations (Table S1).

\subsection{Laboratory analyses}

\subsubsection{Core processing}

Sediment cores were split into halves at the Alfred Wegener Institute (AWI) Helmholtz Centre for Polar and Marine Research with one half being immediately subsampled for radiocarbon dating and subsequently at ca. $10 \mathrm{~cm}$ resolution for proxy analyses. The other half was cleaned and logged for macroscopic lithological changes that permitted the derivation of three lithological units (LU-I to LU-III) and prepared for non-destructive scanning approaches.

\subsubsection{Radiocarbon dating and age-depth modelling}

Due to the lack of suitable plant remains and low organic content of the retrieved sediment core, 25 bulk sediment samples $(0.5 \mathrm{~cm}$ thickness) and one surface sample $(0-0.5 \mathrm{~cm}$ sediment depth) were dated for radiocarbon using accelerator mass spectrometry (AMS) with the Mini Carbon Dating System (MICADAS) at AWI Bremerhaven, Germany (Table 1). Samples were prepared following the standard MICADAS chemical pretreatment procedure (see Gentz et al., 2017, for details).

The age-depth relationship was established by using the open-source MATLAB software package "Undatable" (Lougheed and Obrochta, 2019). For modelling we used 23 bulk sediment samples. Two samples (Lab ID: AWI - 


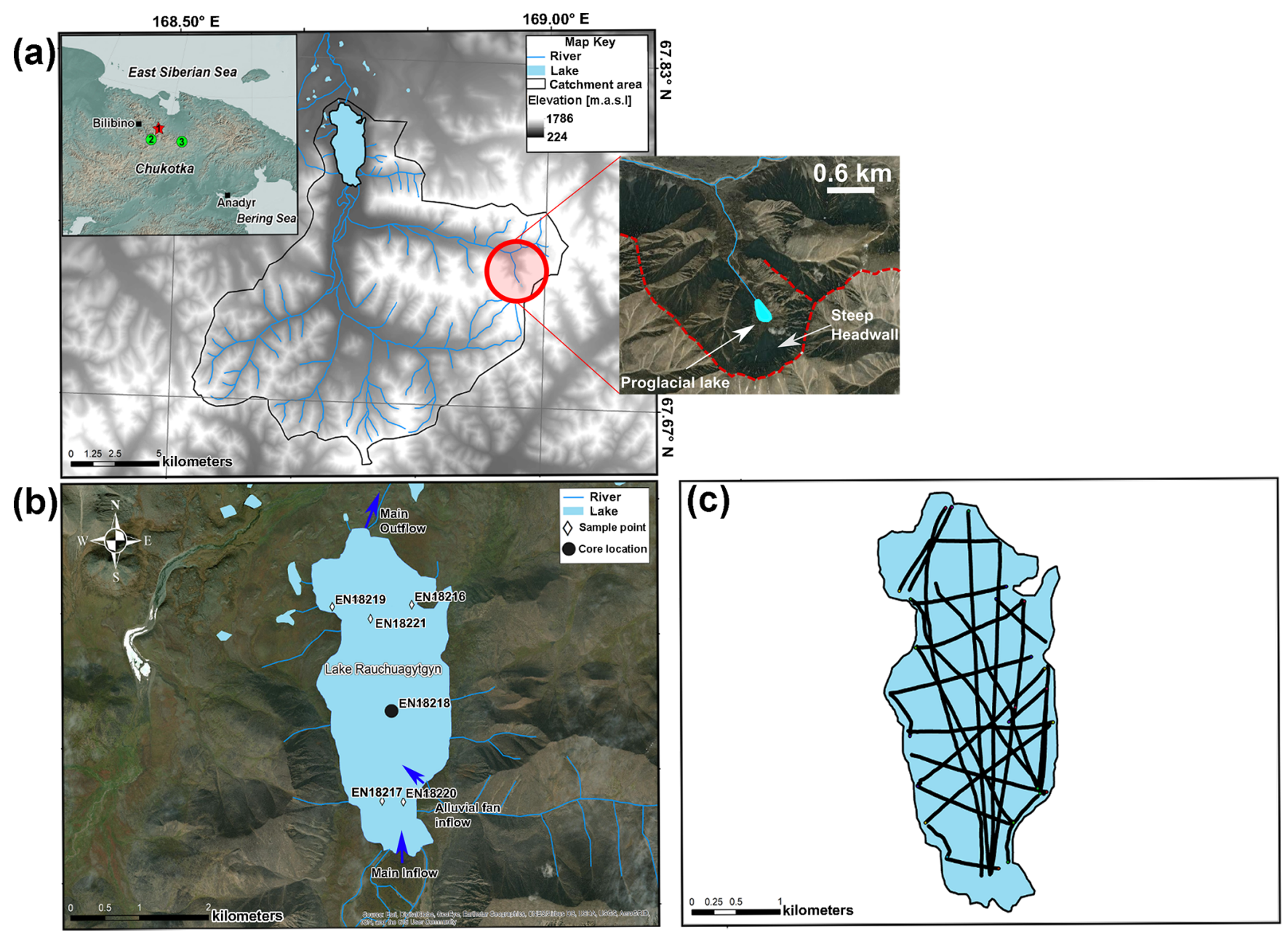

Figure 1. (a) Overview map of the Lake Rauchuagytgyn catchment plotted with a digital elevation map of the Anadyr mountains. The inset shows the situation of Lake Rauchuagytgyn (1) compared to other studied regional lakes: (2) Lake Ilirney and (3) Lake El'gygytgyn (ESRI 2020). A second inset shows the outline of a glacial cirque associated with a small proglacial lake within the eastern catchment. (b) Orthophoto map of the lake and surrounding features. Shown are the locations of surface sampling points and the location of sediment core EN18218 (black dot) as well as an alluvial fan at the lakes' south-eastern margin (ESRI 2020). Flow directions of major inflow and outflow river systems are shown (blue arrows). (c) Lake polygon with all hydroacoustic profile paths retrieved during 2018.

3001.1.1; AWI - 3002.1.1) were slightly older than their successive dates further down, which suggests reworking in these depths (81.25 and $114.75 \mathrm{~cm}$, respectively) and would lead to unrealistically high sedimentation rates when included within age-depth modelling that is not mirrored by sedimentological proxies. We treated these two dates as outliers and excluded them from the modelling process. All dates are given as calibrated years before the present (years before $1950 \mathrm{CE}$, kacal BP) using the IntCal20 calibration curve (Reimer et al., 2020). In order to account for an existing age offset, we added the results from the surface sample $(785 \pm 31$ a) to the software as reservoir age. Within "Undatable", we set the parameters to the following values: $\mathrm{nsim}=10^{6}$, bootpc $=70$ and $\mathrm{xfactor}=0.1$. Each parameter controls the behaviour of the age-depth model generation. The parameter "nsim" is responsible for the number of used iterations; "bootpc" controls the bootstrapping process, i.e. the outlier detection/uncertainty; and "xfactor" determines the uncertainty within the sedimentation accumulation rate between pairs of dating points (Lougheed and Obrochta, 2019). Median sedimentation rates (SRs) $\left(\mathrm{mm} \mathrm{a}^{-1}\right)$ were extracted from the final age-depth model. In order to account for age-depth model uncertainty in subsequent calculations, age-depth-model-derived $1 \sigma$ and $2 \sigma$ sedimentation rate (SR) uncertainty ranges were also extracted.

\subsubsection{Sediment geochemistry, magnetic susceptibility and grain size}

Semi-quantitative sediment geochemical data were obtained by X-ray fluorescence line scanning (XRF) of EN18218 halves. XRF was carried out using an Avaatech core scan- 
Table 1. Radiocarbon dates from sediment core EN18218. Calibrated median ages and $2 \sigma$ confidence intervals were calculated with CALIB 8.2 (Stuiver et al., 2020) using the IntCal20 (Reimer et al., 2020) calibration curve. Calibrated ages are given as calibrated years before the present (years before 1950 CE, kacal BP). The surface sample used for down-core correction of the reservoir effect was not calibrated. Samples in italic and marked with an asterisk $\left(^{*}\right)$ were excluded from the age-depth modelling.

\begin{tabular}{|c|c|c|c|c|c|c|}
\hline Lab code & Sample ID & $\begin{array}{l}\text { Composite } \\
\text { depth }(\mathrm{cm})\end{array}$ & $\begin{array}{r}\text { Radiocarbon } \\
\text { age with error } \\
(\mathrm{a} B \mathrm{BP})\end{array}$ & $\begin{array}{r}\text { Calibrated } \\
\text { median age } \\
(\text { a cal BP) }\end{array}$ & $\begin{array}{r}\text { Calibrated } 2 \sigma \\
\text { age range type } \\
(\text { a cal BP })\end{array}$ & Sample \\
\hline AWI - 5627.1.1 & EN18218-1 Surface $0-0.5 \mathrm{~cm}$ & 0.25 & $785 \pm 31$ & - & - & Bulk, TOC \\
\hline AWI - 2998.1.1 & EN18218-2_0-100_20-20.5 & 18.75 & $2787 \pm 33$ & 2887 & $2783-2961$ & Bulk, TOC \\
\hline AWI - 2999.1.1 & EN18218-2_0-100_36.5-37 & 35.25 & $3629 \pm 33$ & 3942 & $3842-4080$ & Bulk, TOC \\
\hline AWI - 3000.1.1 & EN18218-2_0-100_61-61.5 & 59.75 & $3832 \pm 33$ & 4233 & $4098-4404$ & Bulk, TOC \\
\hline$A W I-3001.1 .1^{*}$ & EN18218-2_0-100_82.5-83 & 81.25 & $4985 \pm 33$ & 5702 & $5602-5882$ & Bulk, TOC \\
\hline$A W I-3002.1 .1^{*}$ & EN18218-2_100-200_116-116.5 & 114.75 & $5417 \pm 34$ & 6234 & $6119-6295$ & Bulk, TOC \\
\hline AWI - 3003.1.1 & EN18218-2_100-200_140-140.5 & 138.75 & $5074 \pm 34$ & 5816 & $5739-5908$ & Bulk, TOC \\
\hline AWI - 3004.1.1 & EN18218-2_100-200_164-164.5 & 162.75 & $5382 \pm 34$ & 6201 & $6008-6284$ & Bulk, TOC \\
\hline AWI - 3005.1.1 & EN18218-2_100-200_189-189.5 & 187.75 & $5852 \pm 34$ & 6672 & $6559-6746$ & Bulk, TOC \\
\hline AWI - 3006.1.1 & EN18218-2_200-240_222.5-223 & 221.75 & $6472 \pm 35$ & 7370 & $7310-7460$ & Bulk, TOC \\
\hline AWI - 3007.1.2 & EN18218-3_0-100_15-15.5 & 248.75 & $8872 \pm 37$ & 10011 & 9779-10177 & Bulk, TOC \\
\hline AWI - 3008.1.1 & EN18218-3_0-100_37-37.5 & 270.75 & $9085 \pm 37$ & 10236 & $10185-10362$ & Bulk, TOC \\
\hline AWI - 3009.1.1 & EN18218-3_0-100_59.5-60 & 293.25 & $9516 \pm 38$ & 10827 & $10604-11074$ & Bulk, TOC \\
\hline AWI - 3010.1.1 & EN18218-3_0-100_83-83.5 & 316.75 & $9901 \pm 39$ & & $11214-11595$ & Bulk, TOC \\
\hline AWI - 3011.1.1 & EN18218-3_100-200_105-105.5 & 338.75 & $10197 \pm 39$ & 11866 & $11655-11994$ & Bulk, TOC \\
\hline AWI - 3012.11 & EN18218-3_100-200_129-129.5 & 362.75 & $11687 \pm 30$ & 13550 & $13481-13598$ & Bulk, TOC \\
\hline AWI - 3013.1.1 & EN18218-3_100-200_150-150.5 & 383.75 & $12205 \pm 46$ & 14112 & $14026-14310$ & Bulk, TOC \\
\hline AWI - 3014.1.1 & EN18218-3_100-200_171-171.5 & 404.75 & $13017 \pm 48$ & 15596 & $15371-15760$ & Bulk, TOC \\
\hline AWI - 3015.1.1 & EN18218-3_200-292_210-210.5 & 443.75 & $14330 \pm 52$ & 17427 & $17197-17803$ & Bulk, TOC \\
\hline AWI - 3016.1.1 & EN18218-3_200-292_239-239.5 & 474.75 & $15686 \pm 48$ & 18941 & $18847-19068$ & Bulk, TOC \\
\hline AWI - 3017.1.1 & EN18218-3_200-292_270-270.5 & 503.75 & $17708 \pm 56$ & 21473 & $21191-21783$ & Bulk, TOC \\
\hline AWI - 3018.1.1 & EN18218-4_0-100_35-35.5 & 536.25 & $18000 \pm 55$ & 21945 & $21740-22117$ & Bulk, TOC \\
\hline AWI - 3019.1.1 & EN18218-4_0-100_64.5-65 & 565.75 & $22649 \pm 66$ & 27059 & $26479-27226$ & Bulk, TOC \\
\hline AWI - 3020.1.1 & EN18218-4_0-100_95-95.5 & 596.25 & $21786 \pm 204$ & 26077 & $25725-26442$ & Bulk, TOC \\
\hline AWI - 3021.1.1 & EN18218-4_100-163_123-123.5 & 624.25 & $25689 \pm 325$ & 29941 & $29205-30735$ & Bulk, TOC \\
\hline AWI - 3022.1.1 & EN18218-4_100-163_145-145.5 & 646.25 & $25081 \pm 300$ & 29393 & $28780-29978$ & Bulk, TOC \\
\hline
\end{tabular}

ner with a Rh X-ray tube at 0.75 and $1.5 \mathrm{~mA}$ for 10 and $15 \mathrm{~s}$, at $10 \mathrm{kV}$ (no filter) and $30 \mathrm{kV}$ (Pd thick filter) at the Federal Institute for Geosciences and Natural Resources (BGR), Germany. A scanning resolution of $5 \mathrm{~mm}$ was chosen. The main rock-forming (Aluminium $(\mathrm{Al})$, Silicon $(\mathrm{Si})$, Calcium (Ca), Potassium (K), Titanium (Ti), Manganese (Mn), Iron $(\mathrm{Fe})$, Rubidium (Rb), Strontium (Sr), Zircon ( $\mathrm{Zr})$ ) and productivity (Bromine $(\mathrm{Br})$ ) linked elements were selected for further processing (Fig. S1). Of these single elements we focus primarily on $\mathrm{Br}, \mathrm{Ca}, \mathrm{K}$ and $\mathrm{Ti}$ within this study. The element ratio of $\mathrm{K} / \mathrm{Ti}$ is used as proxy for clay input and chemical vs. physical weathering (Arnaud et al., 2012; Cuven et al., 2010; Kilian et al., 2013; Marshall et al., 2011). Zr/K and $\mathrm{Si} / \mathrm{Al}$ are included as proxies for coarser grain sizes and $\mathrm{Mn} / \mathrm{Fe}$ for redox conditions (Baumer et al., 2020; Cuven et al., 2010; Píšková et al., 2019). $\mathrm{Br} / \mathrm{Al}$ is utilised alongside $\mathrm{Br}$ as a proxy for productivity (Lenz et al., 2020). Magnetic susceptibility measurements (MSs) were carried out at $1 \mathrm{~mm}$ intervals using a Bartington MS2E spot reading sensor integrated in a fully automatic split-core logging device, devel- oped at the GFZ Potsdam, Germany (Bartington Instruments Ltd). Core images and International Commission on Illumination (CIE) $l^{*}$ (lightness) and $b^{*}$ (blue-yellow) colour data were retrieved using an Avaatech line scan camera. XRF and MS data were smoothed using 5- and 15-point running means respectively.

Sediment grain-size analysis was performed on 63 core samples and 4 surface samples following a 3-week hydrogen peroxide $\left(\mathrm{H}_{2} \mathrm{O}_{2}\right)$ treatment to remove organic matter. Samples were homogenised using an elution shaker for $24 \mathrm{~h}$ and split into eight subsamples. At least three subsamples were analysed thrice, providing overall nine individual measurements using a Malvern Mastersizer 3000 laser diffraction particle analyser (Malvern Panalytical Ltd). The nine measurements were then averaged to produce a grain-size distribution for each sample. Data were processed using GRADISTAT 8.0 software (Blott and Pye, 2001). Intervals of $2 \mathrm{~mm}-$ $63 \mu \mathrm{m}, 63-2$ and $<2 \mu \mathrm{m}$, were used to define percentages of sand, silt and clay respectively (Friedman and Sanders, 
1978). The Folk and Ward method was used for mean grainsize calculation (Folk and Ward, 1957).

\subsubsection{Dry bulk density, elemental analyses and accumulation rate calculations}

Water contents (wt \%) and dry bulk densities (DBDs in $\mathrm{g} \mathrm{cm}^{-3}$ ) were determined using the volumetric approach of Avnimelech et al. (2001) on 63 samples of known volume obtained with a $1 \mathrm{~cm}^{3}$ cube during subsampling and calculated from weight loss following freeze-drying (see also Pajunen, 2000). The total sediment mass accumulation rate (MAR) in $\mathrm{g} \mathrm{cm}^{-2} \mathrm{a}^{-1}$ was calculated according to the Ocean Drilling Program (ODP) methodology (http://www-odp.tamu.edu/, last access: 1 January 2021) (Eq. 1).

$\mathrm{MAR}=\mathrm{DBD} \times \mathrm{SR}$

where DBD is dry bulk density and SR is the age-depthmodel-derived sedimentation rate $\left(\mathrm{cm} \mathrm{a}^{-1}\right)$. MAR uncertainty ranges were determined by applying Eq. (1) to sedimentation rate $1 \sigma$ and $2 \sigma$ uncertainty ranges extracted from the age-depth model.

Subsequently, 65 dried and milled subsamples were analysed for total organic carbon (TOC) and total inorganic carbon (TIC) using a Vario soli TOC cube elemental analyser following combustion at $400^{\circ} \mathrm{C}$ (TOC) and $900^{\circ} \mathrm{C}$ (TIC) (Elementar Corp., Germany). Total carbon (TC) was calculated as the total sum of TOC and TIC. Total sulfur (TS) was measured using an Eltra carbon and sulfur determinator (Eltra $\mathrm{GmbH}$, Germany). Device results are given as weight percent (wt \%) in relation to sample mass. Organic carbon accumulation rates (OCARs) were then calculated by combining TOC (wt \%) and DBD to produce organic carbon content per volume $\left(\mathrm{g} \mathrm{OC} \mathrm{cm}^{-3}\right)$ and then with SR for each depth (Eq. 2).

$\mathrm{OCAR}=\left(\mathrm{DBD} \times\left(\frac{\mathrm{TOC}}{100}\right)\right) \times \mathrm{SR}$

OCARs are reported as grams of organic carbon per square metre per year $\left(\mathrm{g} \mathrm{OC} \mathrm{m}^{-2} \mathrm{a}^{-1}\right)$ for comparison with published organic carbon accumulation rates. OCAR uncertainty ranges were calculated identically to MAR uncertainty ranges.

Average SR, MAR and OCARs were determined for each lithological unit (LU) and the composite sediment succession.

\subsection{Data analyses}

\subsubsection{Estimation of lake basin sediment volumes}

Hydroacoustic profiles were processed and major hydroacoustic boundaries delineated using ISE2 2.9.5 software (Innomar Technologies $\mathrm{GmbH}$ ). Boundary depths were extracted using the ISE2 "depth extraction" tool and were imported into ArcMap 10.5.1 software. Data gaps between measurement points and profiles were interpolated using the "Topo to Raster" tool to produce interpolated depth surfaces to the sediment-water interface and to basin-wide boundary surfaces (Supplement Fig. S3). The interpolated sedimentwater interface depths were subtracted using the raster calculator tool from interpolated boundary depths to estimate total basin and acoustic unit sediment thicknesses $\left(T_{\text {sediment }}\right)$. Sediment volumes $\left(V_{\text {sediment }}\right)$ were subsequently derived from estimated sediment thicknesses using the "Surface Volume" tool (Table 2).

\subsubsection{Estimation of carbon and sediment pools using bootstrapping}

In order to estimate sediment $\left(\mathrm{Sed}_{\text {pool }}, \mathrm{Mt}\right)$ and carbon pools $\left(\mathrm{TOC}_{\mathrm{pool}}, \mathrm{Mt}\right)$ at Lake Rauchuagytgyn, we used an established bootstrapping approach modified from Strauss et al. (2013), Jongejans et al. (2018) and Windirsch et al. (2020) that excluded ice wedges not present within the lake sediments and was enhanced to include sediment volumes estimated from GIS-based methods (Eqs. 3 and 4).

$\begin{aligned} \operatorname{Sed}_{\text {pool }} & =\frac{V_{\text {sediment }} \times \mathrm{DBD}}{10^{6}} \\ \mathrm{TOC}_{\text {pool }} & =\frac{V_{\text {sediment }} \times \mathrm{DBD} \times\left(\frac{\mathrm{TOC}}{100}\right)}{10^{6}}\end{aligned}$

The bootstrapping approach was carried out using the "boot" (version 1.3-25) and "Bootstrapping-permafrost-OC" packages (Canty and Ripley, 2020; Jongejans and Strauss, 2020) in the $\mathrm{R}$ environment and included 10000 iterations of random sampling and replacement of values (Davison and Hinkley, 1997). Combined DBD and TOC values were used for carbon pool estimation and simply DBD for the sediment pool. The approach was applied firstly to the entire sediment core and basin sediment volume and then individually for the LU-II/LU-III (AU2) and LU-I (AU1) sediment packages. The mean sediment and carbon pools (in megatons, Mt), densities $\left(\mathrm{kg} \mathrm{m}^{-3}\right)$, and associated standard deviations and confidence intervals of all iterations were computed (see Strauss et al., 2013, for details) (Supplement S4 Code).

\subsubsection{Multivariate statistics}

In order to reduce data dimensionality and increase interpretability of presented physicochemical sediment stratigraphic and accumulation rate data obtained from core EN18218, principal component analysis (PCA) was carried out following data centring and standardisation by dividing by standard deviation using the "prcomp" function in R ( R Core team, 2013). Probability ellipses were drawn in the resulting PCA biplot for samples included within each lithological unit. 
Table 2. Overview of general acoustic (AU) and lithological unit (LU) divisions with associated depth and age ranges and age-depth model calculated average sedimentation rates (SRs). Additionally shown are basin properties calculated using ArcMap 10.5.1 software including interpolated water and sediment thicknesses $\left(T_{\text {water }}, T_{\text {sediment }}\right)$ and water and sediment package volumes $\left(V_{\text {water }}, V_{\text {sediment }}\right)$.

\begin{tabular}{llrrrrr}
\hline $\begin{array}{l}\text { Acoustic } \\
\text { unit } \\
(\mathrm{AU})\end{array}$ & $\begin{array}{l}\text { Lithological } \\
\text { unit } \\
(\mathrm{LU})\end{array}$ & $\begin{array}{r}\text { Depth range } \\
\text { at core location } \\
(\mathrm{cm})\end{array}$ & $\begin{array}{r}\text { Age } \\
\text { range } \\
(\mathrm{ka} \mathrm{cal} \mathrm{BP})\end{array}$ & $\begin{array}{r}\text { Average } \\
\text { sedimentation } \\
\text { rate }(\mathrm{SR})\left(\mathrm{mm} \mathrm{a}^{-1}\right)\end{array}$ & $\begin{array}{r}\text { Average } \\
\text { interpolated } \\
\text { thickness }(\mathrm{m}) \\
\left(T_{\text {water }}, T_{\text {sediment }}\right)\end{array}$ & $\begin{array}{r}\text { Estimated } \\
\left(V_{\text {water }}, V_{\text {sediment }}\right)\end{array}$ \\
\hline Water & Water & - & - & - & 14.5 & 90103775 \\
\hline 1 & I & $0-346$ & $0-11.69$ & 0.36 & 2.44 & 14935205 \\
\hline 2 & II & LU-II $=346-560$ & $11.69-23.4$ & 0.20 & 2.96 & 18055352 \\
& III & LU-III $=561-653$ & $23.4-$ ca. 29 & 0.17 & & \\
\hline
\end{tabular}

\section{Results}

\subsection{Basin hydroacoustic stratigraphy and sediment distributions}

Hydroacoustic and bathymetric data (Fig. 2) permit the division of the lake basin into four morphological regions: northern shelf, northern sub-basin, southern sub-basin and southern inflow (Fig. 3a). The basin is characterised by steep east and west margins and a central basin bathymetric high. A pronounced river delta is present at the southern lake margin at the major lake inflow (Fig. 1b). An alluvial fan at the lakes' south-eastern margin represents drainage from a steep, lakeproximal, west-east-oriented valley (Fig. 1b). Hydroacoustic data allowed effective imaging of much of the sediment infill except within inflow proximal profiles where acoustic blanking limited data retrieval (Fig. 2b).

Average sediment thickness of the entire lake basin infill is estimated as ca. $5.33 \mathrm{~m}$ with the thickest infill predominantly within the southern sub-basin, and it generally correlates with greater water depth. Average total sediment thickness equates to a total sediment volume of ca. $32990557 \mathrm{~m}^{3}$ $\left(0.033 \mathrm{~km}^{3}\right)$ (Fig. 3d). Sediment thicknesses decrease towards the basin margins, particularly within the northern shelf where water depths $<7.5 \mathrm{~m}$ show reduced sedimentation and evidence of ponded sediment lenses and erosion (Figs. 2b, 3b-d). Comparison of hydroacoustic with lithological data and boundaries from core EN18218 allow the subdivision of basin infill into two acoustic units (AU1 and AU2) corresponding with sediments deposited within lithological units I (AU1) and II and III (AU2) (Table 2). The boundary between AU1 and AU2 represents a major lithological boundary. The base of AU2 likely constitutes the base of sediment infill and is marked by progressively weakening reflectors with depth. Both boundaries trace closely the modernday lake bathymetry (Fig. S3). Acoustic reflectors within AU1 demonstrate generally well-stratified, high-amplitude, continuous, horizontal and sub-parallel reflectors bounded at the top by the sediment-water interface. The thickness of AU1 shows a basin-wide average of $2.44 \mathrm{~m}$ and is thickest within the southern sub-basin proximal to the fluvial inflow and alluvial fan $(6.5-7 \mathrm{~m})$ and thins towards the northern shelf (Fig. 3b). A volume of ca. $14935205 \mathrm{~m}^{3}\left(0.015 \mathrm{~km}^{3}\right)$ was estimated for AU1.

Reflectors within the uppermost portion of AU2 show generally lower amplitude, sub-horizontal, and sub-parallel reflectors and show some continuity with AU1 reflectors (Fig. 2a, b). The lowermost part of AU2 consists of highly discontinuous reflectors with little structure and rare subhorizontal reflectors and likely includes coarse sediments consisting of pebble-sized clasts deposited at the bottom of LU-III directly at the core base and below. The upwards transition to sub-parallel reflectors likely represents sediments deposited within the majority of LU-III and throughout LUII. AU2 is more variable in thickness (average ca. $2.96 \mathrm{~m}$ ) than AU1 but is generally thickest within the southern sub-basin and to a lesser extent within the northern subbasin and at localities close to the northern shelf/northern sub-basin boundary observed within hydroacoustic profiles (Fig. 3c). AU2 possesses a volume of ca. $18055352 \mathrm{~m}^{3}$ $\left(0.018 \mathrm{~km}^{3}\right)$ with complex internal architecture with elevation and depression-like structures and ridges seen within some areas.

\subsection{Core chronology and sedimentation rates}

The age-depth model (Fig. 4a) shows maximum modelled sediment ages of ca. $29 \mathrm{kacalBP}$ at the core base, and thus the core provides an entire record of the Holocene and MIS2. Median sedimentation rates (SRs) are plotted alongside $1 \sigma$ and $2 \sigma$ uncertainty ranges and vary from a maximum of $0.54 \mathrm{~mm} \mathrm{a}^{-1}$ to a minimum of $0.12 \mathrm{~mm} \mathrm{a}^{-1}$ (Fig. 4b). Sedimentation rates are highest within LUI (average $0.36 \mathrm{~mm} \mathrm{a}^{-1}$, average $1 \sigma$ uncertainty 0.25 $0.45 \mathrm{~mm} \mathrm{a}^{-1}$ ). Low intermediate but progressively increasing rates are seen within LU-II (average $0.20 \mathrm{~mm} \mathrm{a}^{-1}$, average $1 \sigma$ uncertainty $\left.0.16-0.23 \mathrm{~mm} \mathrm{a}^{-1}\right)$ with pronounced peaks at 510.5 and $371 \mathrm{~cm}$. LU-III demonstrates low rates but with larger uncertainty (average $0.17 \mathrm{~mm} \mathrm{a}^{-1}$, average $1 \sigma$ uncertainty $0.15-0.27 \mathrm{~mm} \mathrm{a}^{-1}$ ) due to age model scatter. 

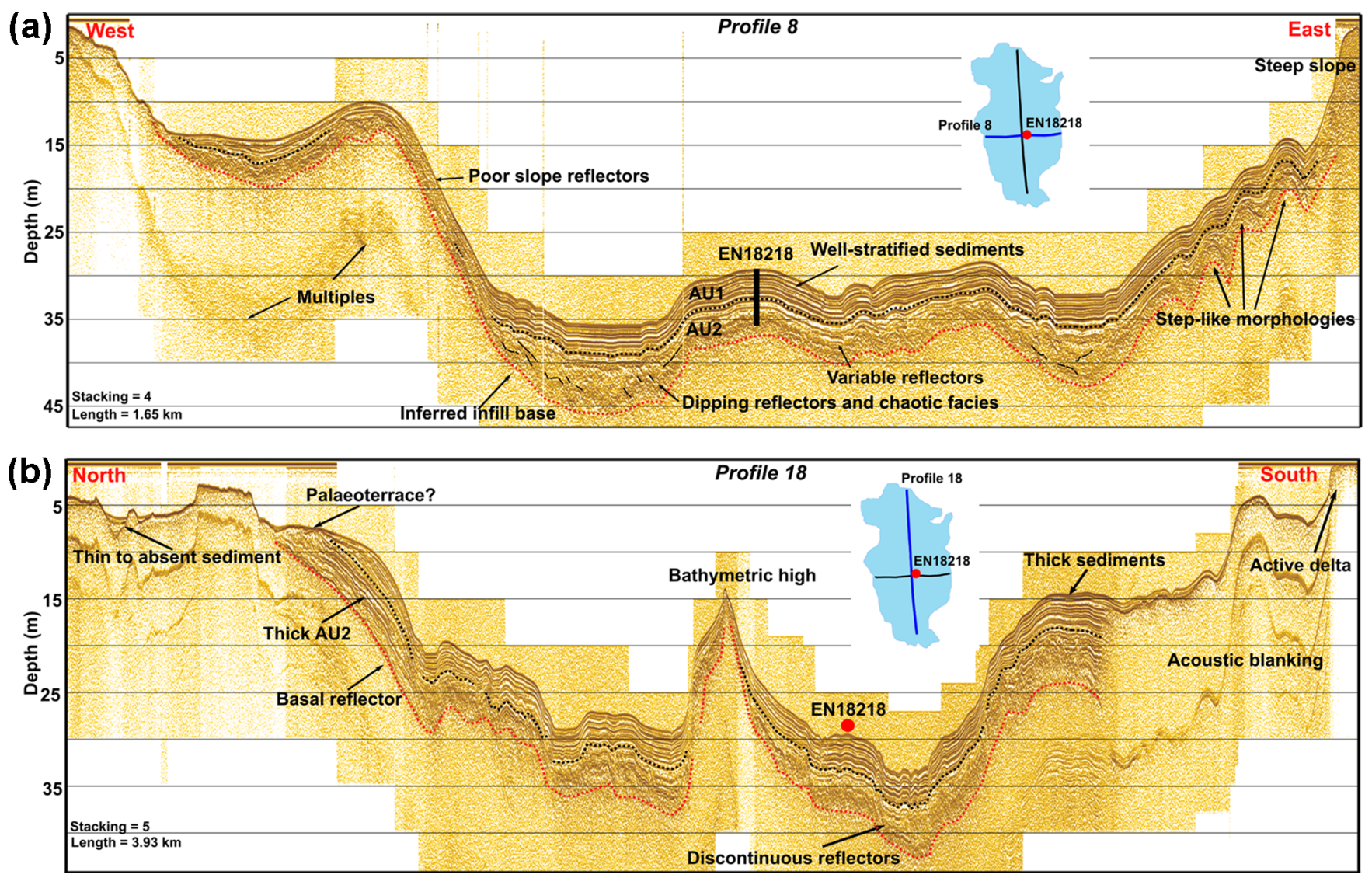

Figure 2. Interpreted hydroacoustic profiles from Lake Rauchuagytgyn (profile 8 and profile 18). Both profiles pass close to the drilling location of EN18218. Shown are inferred major hydroacoustic boundaries defined that are connected with major lithological changes recorded by EN18218 and interpreted across the basin.

Changes in sedimentation rates generally correspond with major lithological variations. Sedimentation rate reductions occur at the LU-III-LU-II (ca. $560 \mathrm{~cm}$ ) boundary, and increases are observed across the LU-II-LU-I (ca. $346 \mathrm{~cm}$ ) boundary (Fig. 4a, b).

\subsection{Core sedimentological and biogeochemical characteristics}

LU-III (Table 2) represents the lowermost unit of core EN18218 and comprises very poorly sorted, coarse material consisting of pebble-sized clasts directly at the core base of LU-III (ca. $653 \mathrm{~cm}$ ) that blocked further core retrieval. Coarse basal sediment is then succeeded by overlying, yellow-grey, light-coloured (low $b^{*}$ ), and layered siltyclay sediments from ca. 653 to $560 \mathrm{~cm}$. Sediments within LU-III show low water contents (average $39.5 \%$ ), high DBD (average $1.22 \mathrm{~g} \mathrm{~cm}^{-3}$ ), very high magnetic susceptibility values (average $681\left[10^{-6} \mathrm{SI}\right]$ ) and low mean grain sizes (average $3.9 \mu \mathrm{m}$ ) traced by $\mathrm{Zr} / \mathrm{K}, \mathrm{Si} / \mathrm{Al}$ and $\mathrm{K} / \mathrm{Ti}$ ratios (Figs. 5, 6). The grain-size distribution shows a predominance of silt clay with minor sand concentrated just above the core base (ca. $650.5 \mathrm{~cm}$ ). MARs vary between $0.029 \mathrm{~g} \mathrm{~cm}^{-2} \mathrm{a}^{-1}$ at the core base and $0.019 \mathrm{~g} \mathrm{~cm}^{-2} \mathrm{a}^{-1}$ at the top of LU-III (average $0.022 \mathrm{~g} \mathrm{~cm}^{-2} \mathrm{a}^{-1}$, average $1 \sigma$ uncertainty 0.019 $0.034 \mathrm{~g} \mathrm{~cm}^{-2} \mathrm{a}^{-1}$ ) but are associated with high uncertainty in the positive sigma direction (Fig. 4). TOC contents (wt \%) (average $0.27 \%$ ) and $\mathrm{Br} / \mathrm{Al}$ ratio values demonstrate their lowest values within LU-III alongside TC (average $0.28 \%$ ) and TS (average $0.018 \%$ ) (Fig. 6). OCARs are extremely low and stable with low uncertainty (average $0.58 \mathrm{~g} \mathrm{OC} \mathrm{m}^{-2} \mathrm{a}^{-1}$, average $1 \sigma$ uncertainty $0.50-0.92 \mathrm{~g} \mathrm{OC} \mathrm{m}^{-2} \mathrm{a}^{-1}$ ). Equally, $\mathrm{Mn} / \mathrm{Fe}$ shows stable, low values. The LU-III-LU-II boundary is characterised by a decrease in magnetic susceptibility and increase in the $\mathrm{K} / \mathrm{Ti}$ ratio corresponding to finer grain sizes at around $560 \mathrm{~cm}$ with a grain-size minimum $(2.3 \mu \mathrm{m})$ at $550 \mathrm{~cm}$. This corroborates a change in sediment lithology to non-layered, very fine-fine silty grey-coloured sediments in LU-II. Sediment grain size increases around $506 \mathrm{~cm}$ and again around $483 \mathrm{~cm}$ clearly viewed by an increase in the $\mathrm{Zr} / \mathrm{K}$ ratio and a peak in mean grain size marking an increasing contribution of sand and coarser silts to the particle size distribution. Following a unit maximum in grain size at $431 \mathrm{~cm}(5.1 \mu \mathrm{m})$ a decrease is observed with a value at $391 \mathrm{~cm}$ similar to the unit average of $3.82 \mu \mathrm{m}$. Grain size then 
(a)

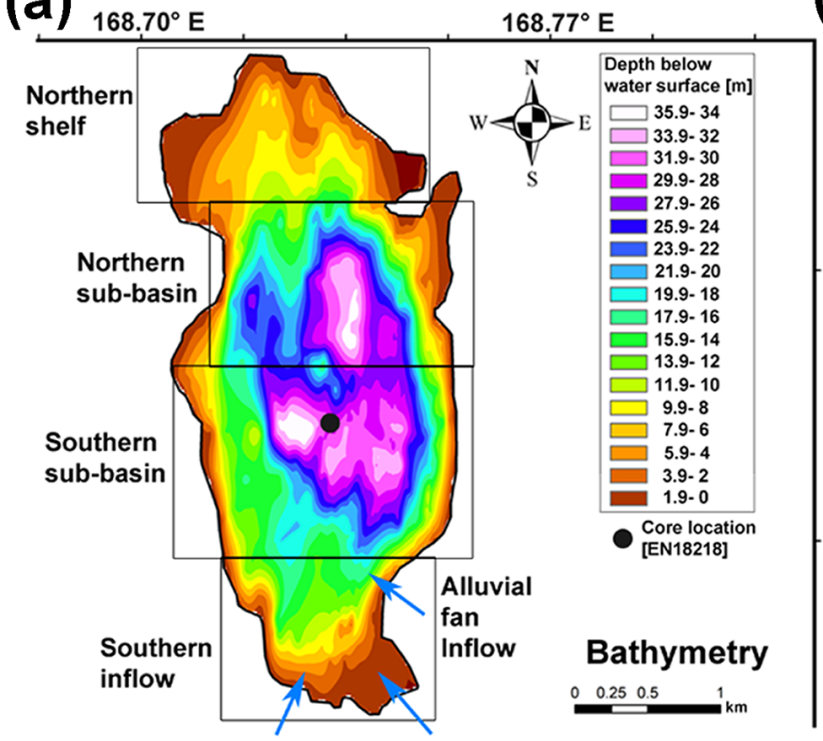

(b) $168.70^{\circ} \mathrm{E}$ $168.77^{\circ} \mathrm{E}$

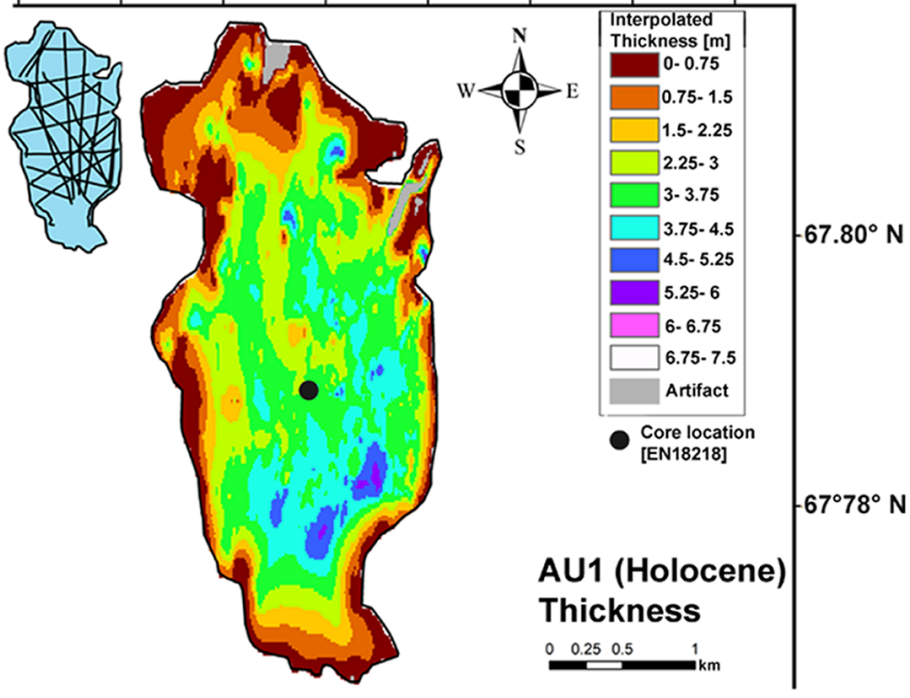

(c)

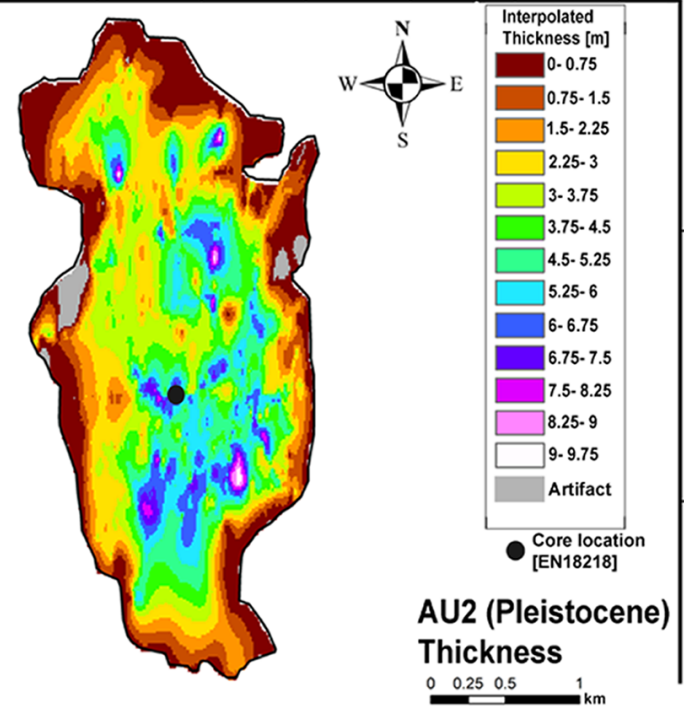

(d)

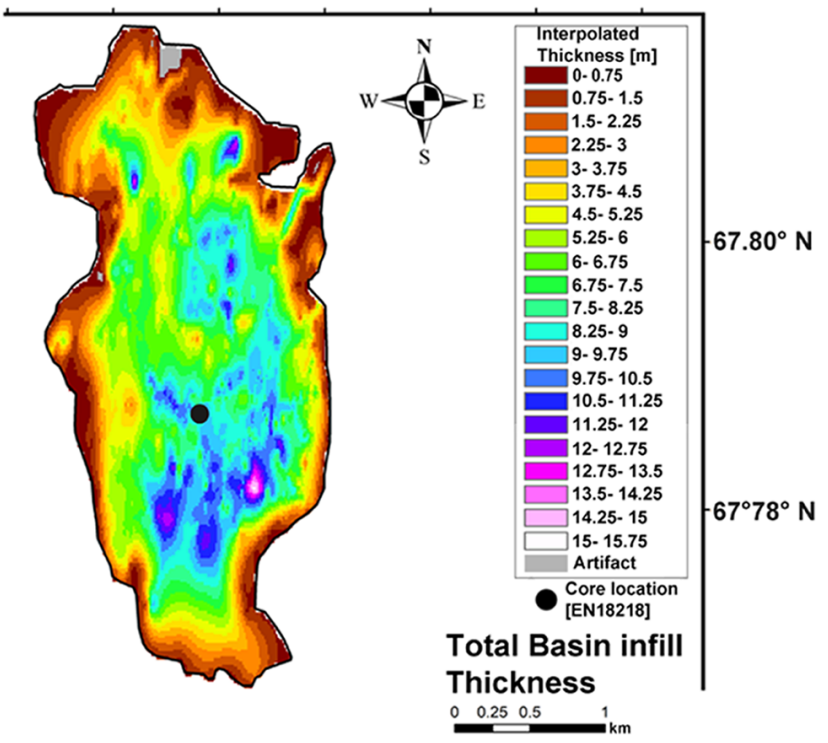

Figure 3. (a) Interpolated high-resolution lake bathymetry with morphological regions denoted by black boxes. (b) Interpolated AU1 thicknesses. Blue and pink colours denote the thickest sediment within the southern sub-basin. (c) Interpolated sediment thicknesses within AU2. Similarly to AU1, the greatest thicknesses are predominantly located in the southern sub-basin but with other locations in the northern-sub basin showing thick sediments too. (d) Whole sediment package interpolated thickness. Thin sediment is found proximal to the basin margins and at the north-western shelf. The sediment distribution generally reflects sediment focussing into the deeper lake at greater water depths. Interpolation artefacts are attributed to data sparsity and difficulty in tracing reflectors in some regions due to acoustic blanking that led to erroneous interpolation. Larger artefacts were hence excluded.

rises towards the LU-II-LU-I transition at $346 \mathrm{~cm}$. Water content is significantly higher (average $51.8 \%$ ) and dry bulk density lower (average $0.87 \mathrm{~g} \mathrm{~cm}^{-3}$ ) than in LU-III. MARs are generally lower than in LU-III, associated with lower uncertainty (average $0.017 \mathrm{~g} \mathrm{~cm}^{-2} \mathrm{a}^{-1}$, average $1 \sigma$ uncertainty $0.013-0.019 \mathrm{~g} \mathrm{~cm}^{-2} \mathrm{a}^{-1}$ ), and follow variations in sedimentation rate with maxima at ca. 510.5 and $380-371 \mathrm{~cm}$. TOC and TC values are significantly higher in LU-II (av- erage TOC $0.77 \%$, average TC $0.78 \%$ ) and increase concomitantly to a maximum $(>2 \% \mathrm{C})$ at the LU-II-LU-I transition in line with gradually darkening sediment colour and increasing $\mathrm{Br} / \mathrm{Al}$ to brown-coloured fine silts at the top of the unit. The average OCAR in LU-II is more than double LU-III (average $1.32 \mathrm{~g} \mathrm{OC} \mathrm{m}^{-2} \mathrm{a}^{-1}$, average $1 \sigma$ uncertainty $\left.1.03-1.48 \mathrm{~g} \mathrm{OC} \mathrm{m}^{-2} \mathrm{a}^{-1}\right)$ and rises from a minimum at $550 \mathrm{~cm}\left(0.72 \mathrm{~g} \mathrm{OC} \mathrm{m}^{-2} \mathrm{a}^{-1}\right)$ to a unit maximum at $371 \mathrm{~cm}$ 


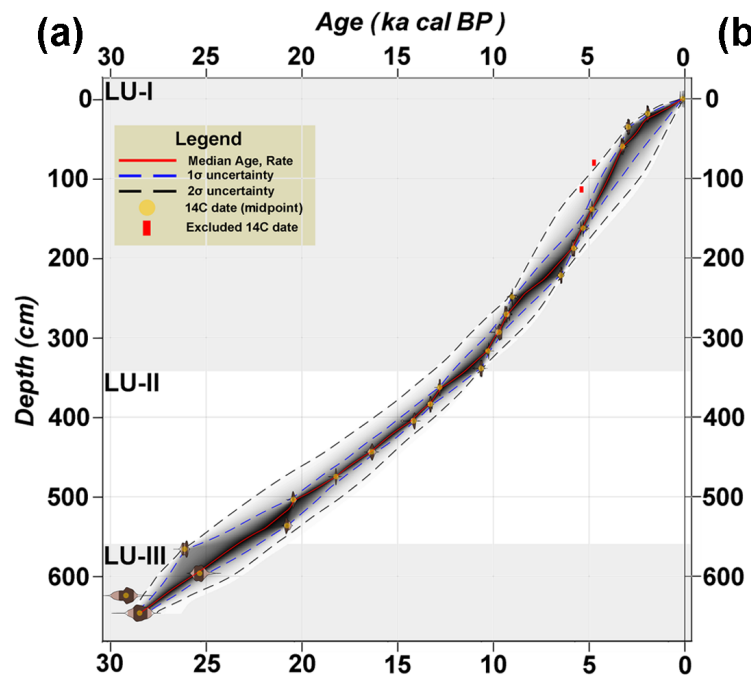

(b) Sedimentation rate (SR) $\left(\mathrm{mm} \mathrm{a}^{-1}\right)$
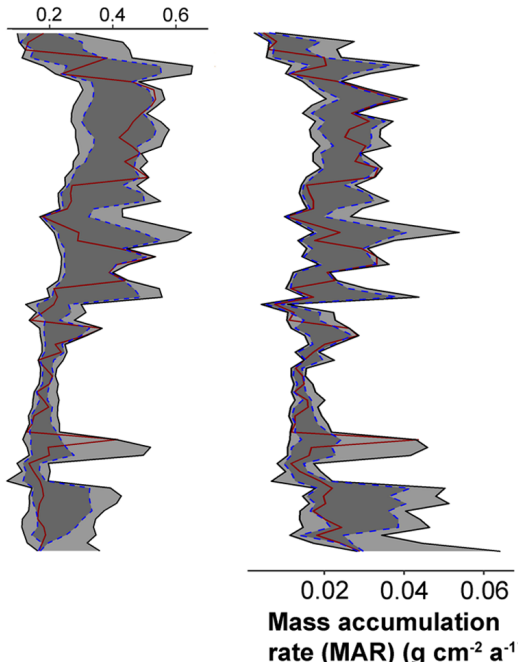

Figure 4. (a) High-resolution age-depth model for sediment core EN18218 created from 23 radiocarbon dates with sigma uncertainty range. (b) Sedimentation and mass accumulation rates (dark red lines) and $1 \sigma$ and $2 \sigma$ uncertainty ranges (dark and light grey ribbons).

(2.67 $\left.\mathrm{g} \mathrm{OC} \mathrm{m}^{-2} \mathrm{a}^{-1}\right)$. TS shows higher values within LUII (average TS $0.04 \%$ ) and increases in the upper part towards the LU-II-LU-I boundary at $346 \mathrm{~cm}$. Nonetheless TS contributes very little to the total core biogeochemistry. The $\mathrm{Mn} / \mathrm{Fe}$ ratio is more variable within LU-II and gradually increases from the LU-III-LU-II boundary upwards, forming a plateau $472-363 \mathrm{~cm}$ before decreasing towards the LU-IILU-I transition.

LU-I is typified by dark-coloured, fine-silt sediments of coarser grain size than observed for all other units (average $6.5 \mu \mathrm{m}$ ) mirrored by $\mathrm{Zr} / \mathrm{K}, \mathrm{Si} / \mathrm{Al}$ and $\mathrm{K} / \mathrm{Ti}$ ratios. MARs achieve high values particularly between 311 and $251 \mathrm{~cm}$ and between 181.5 and $61.5 \mathrm{~cm}$, consistent with sedimentation rates (average $0.022 \mathrm{~g} \mathrm{~cm}^{-2} \mathrm{a}^{-1}, 1 \sigma$ uncertainty $0.015-$ $\left.0.028 \mathrm{~g} \mathrm{~cm}^{-2} \mathrm{a}^{-1}\right)$. TOC and TC contents attain their highest values (average TOC $1.62 \%$, average TC $1.63 \%$ ) with a prominent maximum just after the LU-II-LU-I boundary $(\mathrm{ca} .341 \mathrm{~cm})$ and unit minimum $(1.2 \%)$ between 261 and $251 \mathrm{~cm}$ before increasing to values $>2 \%$ at the modern sediment surface. $\mathrm{Br} / \mathrm{Al}$ follows TOC and TC and increases slightly throughout the unit towards the sediment surface. TS demonstrates a broad peak between 371 and $271 \mathrm{~cm}$ commensurate with extremely low $\mathrm{Mn} / \mathrm{Fe}$ ratio values. TS values then decrease and remain low with the exception of a maximum at the sediment-water interface. OCARs are significantly higher than in LU-II and LU-III, associated with higher uncertainty, and vary between 1.56 and $6.3 \mathrm{~g} \mathrm{OC} \mathrm{m}^{-2} \mathrm{a}^{-1}$ (average $3.53 \mathrm{~g} \mathrm{OC} \mathrm{m}^{-2} \mathrm{a}^{-1}$, average $1 \sigma$ uncertainty $2.46-4.46 \mathrm{~g} \mathrm{OC} \mathrm{m}^{-2} \mathrm{a}^{-1}$ ) with values increasing across the LU-II-LU-I transition to high values between 311 and $271 \mathrm{~cm}$ generally consistent with higher TS and the $\mathrm{Mn} / \mathrm{Fe}$ minimum. High OCARs are also observed be- tween around 181.5 and $41.5 \mathrm{~cm}$ alongside high SRs and MARs, in line with increasing TOC contents (maximum $6.3 \mathrm{~g} \mathrm{OC} \mathrm{m}^{-2} \mathrm{a}^{-1}$ ).

\subsection{Lake carbon and sediment pools}

Average sediment thicknesses and volumes are similar between both sediment packages but slightly greater within the LU-II/LU-III (AU2) package (Table 2). The total carbon pool $\left(\mathrm{TOC}_{\text {pool }}\right)$ calculated amounts to $0.26 \pm 0.02 \mathrm{Mt}$ with a respective average carbon density (TOC density) of $7.85 \pm 0.60 \mathrm{~kg} \mathrm{~m}^{-3}$. LU-II and LU-III sediments at Lake Rauchuagytgyn displayed the lowest estimates with around $0.1 \pm 0.007 \mathrm{Mt}$ of carbon stored and a TOC density of $5.65 \pm 0.40 \mathrm{~kg} \mathrm{~m}^{-3}$ when compared with the more-carbonrich LU-I sediments $\left(\mathrm{TOC}_{\text {pool }}=0.15 \pm 0.005 \mathrm{Mt}\right.$, TOC density $\left.=9.87 \pm 0.34 \mathrm{~kg} \mathrm{~m}^{-3}\right)$. The total calculated sediment pool for total sediment mass deposited was estimated via bootstrapping as $25.7 \pm 1.71 \mathrm{Mt}$ with an average sediment density of $780 \pm 52 \mathrm{~kg} \mathrm{~m}^{-3}$. Individual calculation of sediment pools in LU-I and LU-II/LU-III yielded values of $9.33 \pm 0.32$ and $17.1 \pm 0.89 \mathrm{Mt}$ respectively.

\subsection{Results of principal component analysis}

The PCA biplot (Fig. 7) of sedimentological, biogeochemical and accumulation rate data shows that PC1 (59.7\%) and PC2 $(12.0 \%)$ together explain $71.7 \%$ of the total variance within the dataset. A clear division and clustering of data is observed that confirms the lithological unit definition and the main data trends described in Sect. 4.2 and 4.3. The variance in the positive $\mathrm{PC} 1$ direction is controlled chiefly by productivity variables $\left(\mathrm{TOC}, \mathrm{TC}, \mathrm{Br} / \mathrm{Al}, \mathrm{Br}, \mathrm{TS}, b^{*}\right.$ ), grain 


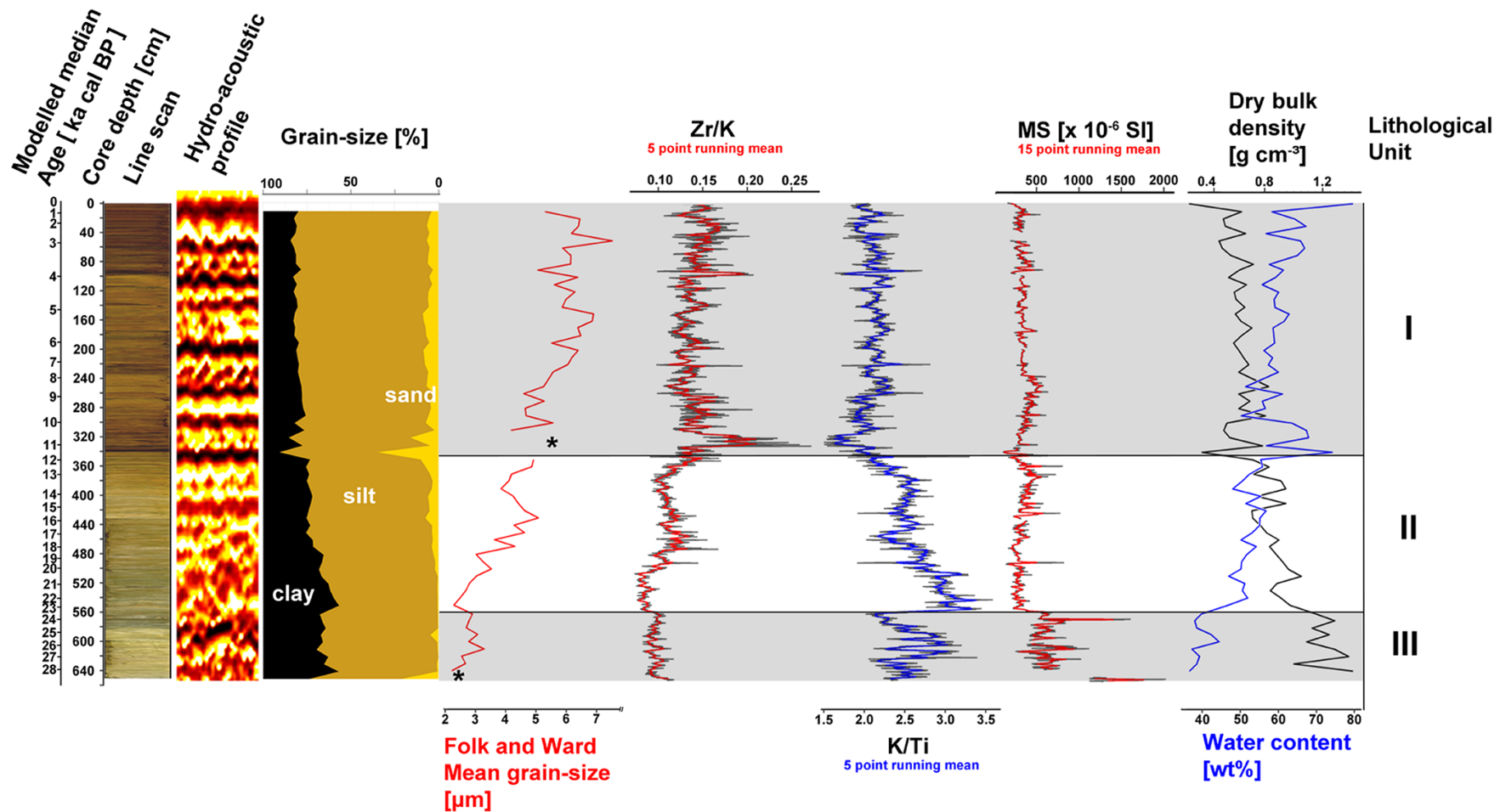

Figure 5. Sedimentological and sediment-geochemical proxies obtained from core EN18218 including measured grain sizes, XRF grainsize proxies, magnetic susceptibility water content and dry bulk density alongside the hydroacoustic profile from the drilling location and lithological unit derivation (Grey-boxes). * In mean grain-size plot refers to three excluded data points $(650.5,341,321 \mathrm{~cm})$ of coarser mean grain size (up to $25 \mu \mathrm{m}$ ).

size (sand, silt, mean GS, $\mathrm{Zr} / \mathrm{K}, \mathrm{Si} / \mathrm{Al}$ ), and to a lesser degree sedimentation (SR) and accumulation rates of carbon (OCAR). Negative values of PC1 are explained by reduced organic content, increasing fine-grained contribution of clay, increased DBD, light colouration $\left(l^{*}\right)$ and MS, Ti, Ca, K, and $\mathrm{K} / \mathrm{Ti}$. The mass accumulation rate controls chiefly variance within the PC2 direction (Figs. 7, S4).

\section{Discussion}

\subsection{Accumulation history of Lake Rauchuagytgyn in a palaeoenvironmental context}

\subsubsection{Glacially influenced sediment and carbon accumulation during the early Marine Isotope Stage 2 (ca. 29-23.4 ka cal BP)}

Coarse sediments found directly at the base of core EN18218 consisting of pebble-sized clasts that prevented further core retrieval, alongside discontinuous and occasionally chaotic hydroacoustic reflectors within the lowermost portion of AU2, may suggest that the lake bottom substrate represents a diamicton that shares some similarities with basal sediments reported from other Arctic lake sites (cf. Finkenbinder et al., 2014). The presence of pebble-sized clasts may imply that a lacustrine environment either was totally absent during deposition of the basal sediment or was dry for long periods of time. Basal structures observed within hydroacoustic data within the lower portion of AU2 may suggest a mixed origin of the coarse sediment that may be related to fluvial or possibly glaciofluvial activity within the basin that subsequently influenced basin sediment distributions (cf. Lebas et al., 2019, 2021). A lack of detailed sedimentological data of core base sediment, due to poor retrieval and limited penetration, however, limits the further comprehensive interpretation of the lake bottom substrate within this study. Although radiocarbon ages show scatter throughout LU-III, a modelled core base age of around $29 \mathrm{kacal}$ BP generally overlaps in timing with MIS2 recorded by other regional records and prominent Alaskan lake records (Asikainen et al., 2007; Finkenbinder et al., 2014; Vyse et al., 2020). Moreover, basal ages of several large northern latitude lakes, including dated basal diamicton from Harding Lake, Alaska, show generally agreeable age overlap with coarse basal sediment preserved at Lake Rauchuagytgyn (Anderson and Lozhkin, 2015; Brosius et al., 2021; Finkenbinder et al., 2014).

Overlying layered sediments pervasive throughout LUIII that are characterised by high magnetic susceptibility, dry bulk density and silty-clay composition may suggest the presence of a lake-proximal glacier and the concurrent depo- 


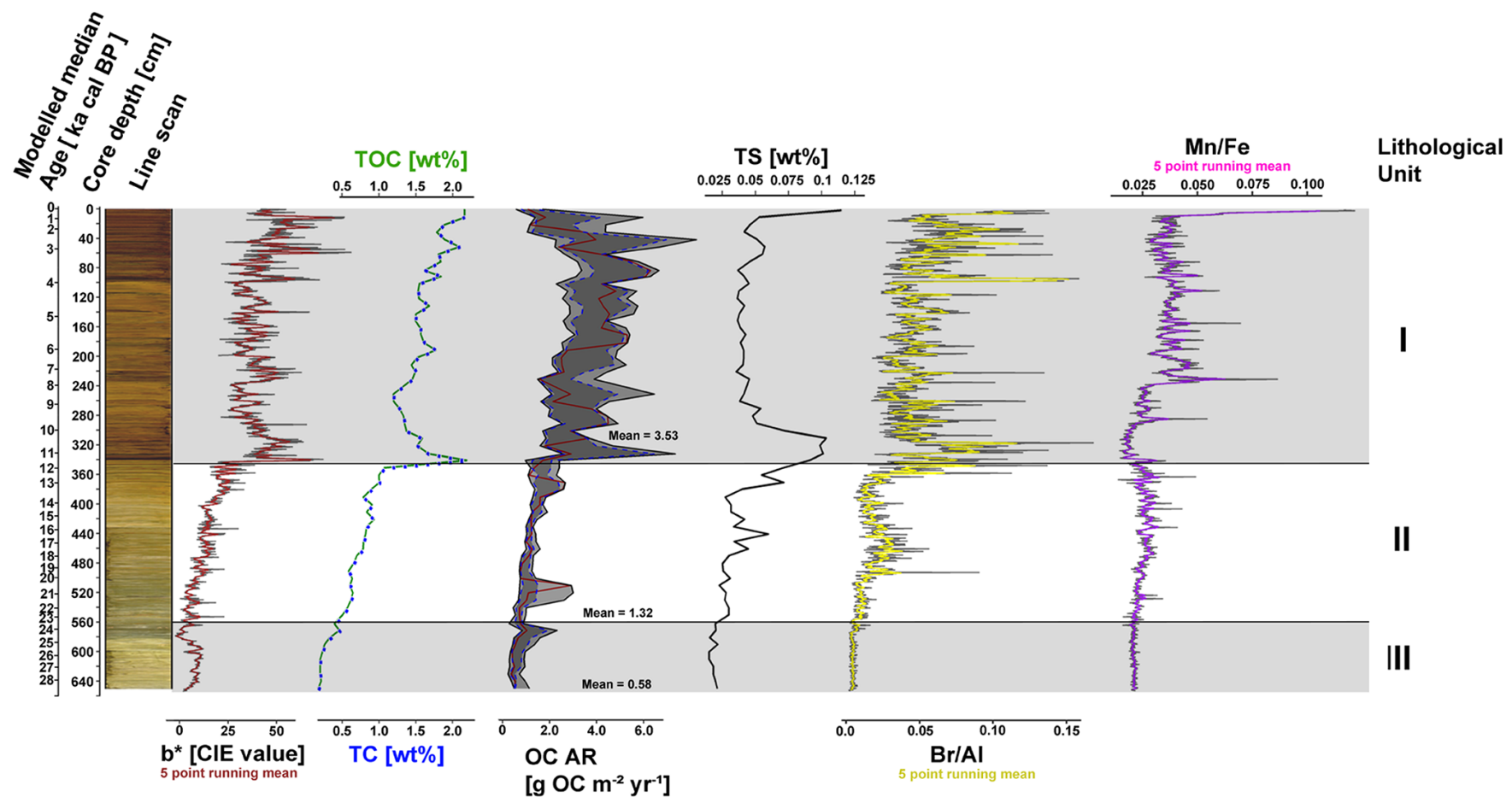

Figure 6. Biogeochemical proxies measured from samples obtained from core EN18218 (TOC, TC, TS) as well as from XRF (Br/Al, $\mathrm{Mn} / \mathrm{Fe}$ ) and line scanning $\left(b^{*}\right)$. Average OCAR (Red line) is plotted alongside sigma uncertainty ranges (grey ribbons) synonymous with descriptions in Fig. 4.

sition of minerogenic, predominantly fine-grained, glacially derived suspended load to the lake basin within a glaciolacustrine setting (cf. Bakke et al., 2005; Gromig et al., 2019; Karlen and Matthews, 1992; Leemann and Niessen, 1994b; Van der Bilt et al., 2015). This may be further supported by an abundance of the minerogenic elements $\mathrm{Ca}$, Ti and $\mathrm{K}$ throughout LU-III, a light sediment colouration, and very low organic content that suggest deposition of organicpoor, minerogenic material derived from a catchment glacier (Fig. 7). The fingerprint of minerogenic, glacially derived suspended load sediment may plausibly be represented by strongly negative PC1 scores from principal component analysis clustered within LU-III of the PCA biplot (Fig. 7) (cf. Van der Bilt et al., 2015). Catchment conditions during deposition of LU-III were likely cold with minimal within-lake and catchment vegetation productivity indicated across all biogeochemical proxies. Extremely low OCARs during the early MIS2 of ca. $0.58 \mathrm{~g} \mathrm{OC} \mathrm{m}^{-2} \mathrm{a}^{-1}$ suggest minimal organic carbon input to the basin sediment that was predominantly autochthonous in origin with very limited contribution from catchment vegetation (Kokorowski et al., 2008a). Lacustrine palynological records and vegetation reconstructions of the catchment surrounding Lake Ilirney (ca. $50 \mathrm{~km}$ south) during MIS2 agree well with cold conditions with low pollen productivity of catchment flora represented by low pollen concentrations (Andreev et al., 2021). In ad- dition, pollen reconstructed July temperatures was $4-5^{\circ} \mathrm{C}$ lower than modern, in agreement with unfavourable climate conditions for organic carbon productivity (Andreev et al., 2021). Sedimentological records from Lake Ilirney during MIS2 also agree with extremely low within-lake productivity represented by very low TC and absent diatoms (Vyse et al., 2020). Preliminary diatom analyses also show a complete absence of diatoms within LU-III, in line with cold and possibly turbid water conditions (Biskaborn, unpublished data; Finkenbinder et al., 2014). Organic material arriving at the sediment-water interface was likely preserved by lowoxygen conditions. This is recorded by low and stable values of the XRF-derived $\mathrm{Mn} / \mathrm{Fe}$ ratio that well represents the redox conditions at the sediment-water interface (cf. Baumer et al., 2020; Biskaborn et al., 2019; Fritz et al., 2018; Heinecke et al., 2017; Naeher et al., 2013; Píšková et al., 2019).

Finer grain sizes directly measured by laser diffraction are supported by indirect, XRF-derived grain-size proxies for finer, clay-dominated sediment $(\mathrm{K} / \mathrm{Ti})$ and of coarser sediment $(\mathrm{Zr} / \mathrm{K}, \mathrm{Si} / \mathrm{Al})$. Fine-grained composition likely reflects deposition beneath a quasi-permanent lake ice layer that further reduced within-lake productivity through limiting light penetration with insufficient irradiance required by algal communities and hence diminishing organic matter export to the hypolimnion (Andersen et al., 1993; Bouchard et al., 2011; Croudace and Rothwell, 2015; Cuven et al., 


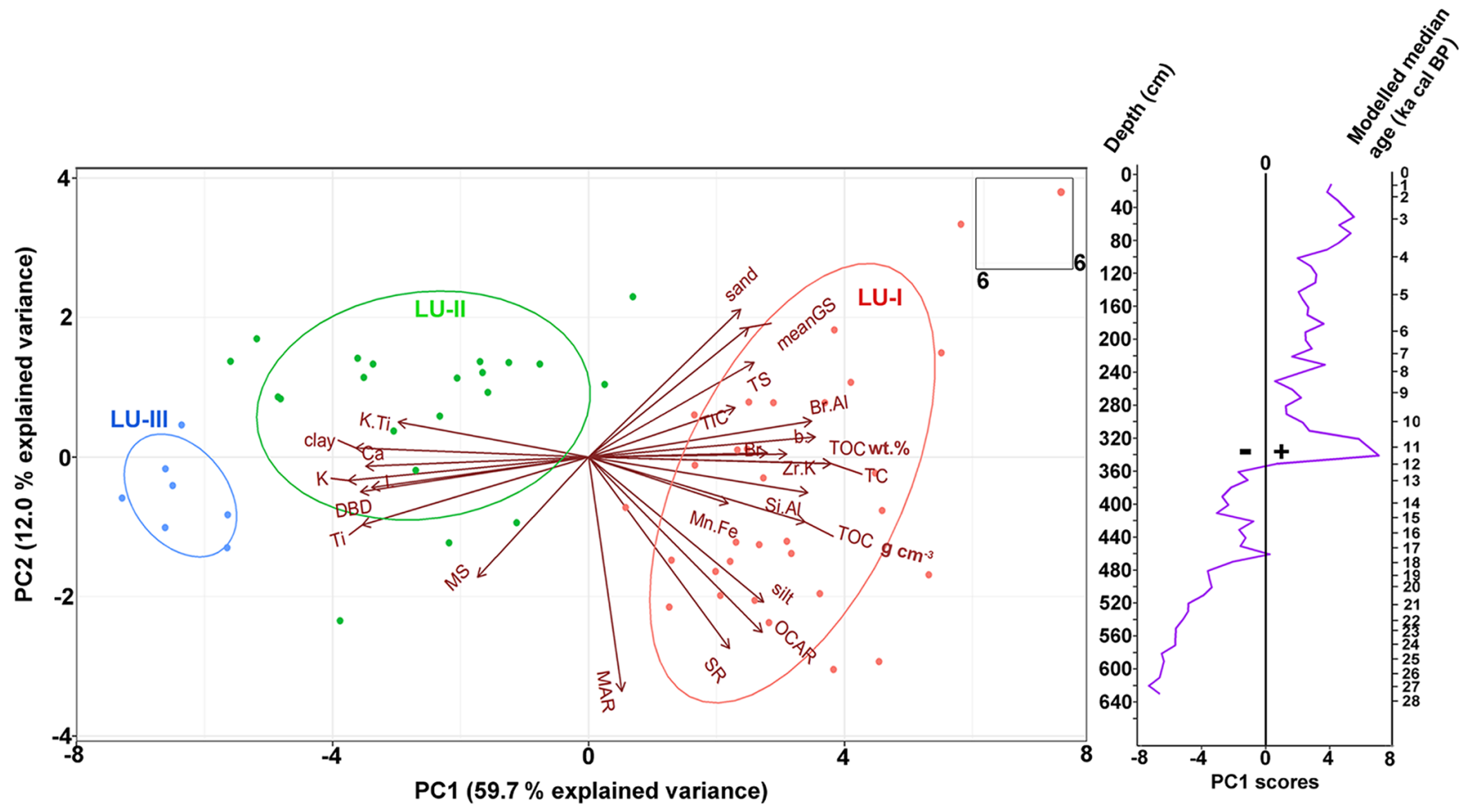

Figure 7. Principal component analysis biplot of sedimentological, biogeochemical and accumulation rate data from core EN18218. Samples are coloured and clustered according to their lithological unit definitions (LU-III, LU-II, LU-I). Also shown are the PC1 scores plotted stratigraphically in relation to depth and modelled age.

2010; McLaren and Bowles, 1985). Thus, during deposition of minerogenic sediment within LU-III the lake may have been of cold-monomict type (Cremer and Wagner, 2003). Sediment input at Lake Rauchuagytgyn was generally low during LU-III deposition as represented by comparatively low SRs and MARs and was likely temporally continuous, with no evidence of unconformities found within sedimentological data. The uncertainty in the positive sigma direction may suggest that rates could be higher when integrating uncertainty associated with age inversions within LU-III. Sedimentation rates reported for Lake El'gygytgyn crater lake (Fig. 1) were low during MIS2 (4.8 $\left.\mathrm{cm} \mathrm{kyr}^{-1}\right)$, compared to higher rates $\left(7.6 \mathrm{~cm} \mathrm{kyr}^{-1}\right)$ during the Holocene (Nowaczyk et al., 2007). A similar finding was made for Harding Lake in Alaska whereby sedimentation rates during the Last Glacial Maximum (30.7 to $15.7 \mathrm{ka}$ ) were generally $<0.1 \mathrm{~mm} \mathrm{yr}^{-1}$ but temporally continuous throughout deposition (Finkenbinder et al., 2014). In both of these settings, low sedimentation rates were interpreted as a consequence of thick, quasipermanent lake surface ice cover and an extremely thin or absent catchment tundra active layer during cold episodes that reduced catchment sediment delivery and wind-driven sediment redistribution (Asikainen et al., 2007; Francke et al., 2013; Melles et al., 2007). Moreover, a similar observation at Lake Karakul, Tajikistan, of lower sedimentation rates during MIS2 since ca. $29 \mathrm{ka} \mathrm{cal} \mathrm{BP}\left(0.15 \mathrm{~mm} \mathrm{a}^{-1}\right)$ when compared with Holocene sedimentation rates $\left(0.84 \mathrm{~mm} \mathrm{a}^{-1}\right)$ was also explained by reduced sediment input during MIS2 compared to the Holocene alongside reduced organic matter accumulation (Heinecke et al., 2017). The low sedimentation and mass accumulation rates at Lake Rauchuagytgyn during the early MIS2 and the late glacial may be supported by the generally equitable thicknesses and sediment volumes between the AU2 (LU-II/LU-III) and AU1 (LU-I) sediment packages derived hydroacoustically (Table 2). Differences are, however, observed when MIS2 accumulation rates are compared with other Siberian glacial lake sites including Lake Bolshoye Shchuchye in the Ural Mountains (average Last Glacial Maximum (LGM) $1.68 \mathrm{~mm} \mathrm{a}^{-1}$ ). Lake Bolshoye Shchuchye demonstrates a voluminous LGM sediment package $\left(0.325 \mathrm{~km}^{3}\right) 6$ times the volume of the Holocene sediment package $\left(0.05 \mathrm{~km}^{3}\right)$, which shows markedly lower sedimentation rates $\left(0.36 \mathrm{~mm} \mathrm{a}^{-1}\right)$ and is interpreted to result from intense glacial erosion of the catchment during the LGM (Haflidason et al., 2019).

The difference in glacial sediment accumulation between sites may relate to multiple interacting factors including the duration of lake surface ice cover, the thickness of the catchment active layer, the existence/absence of deep-water conditions and also differences in glacier dynamics between catchments (Asikainen et al., 2007; Francke et al., 2013). Remotesensing-based studies of Chukotkan glacial geomorphology 
and structures within the Rauchua valley have suggested the presence of a passive catchment glacier ca. $25 \mathrm{~km}$ in length that extended along the length of the Rauchua River valley and discharged into the Rauchuagytgyn basin during marine isotope stage 2 (Glushkova, 2011). Thus, the catchment glacier may have been predominantly non-erosive during the early MIS2 and hence not contributed significant sediment volume to the lake basin supporting the low rates of sediment and mass accumulation discussed here (Gurnell et al., 1996). It must be, however, noted that the radiocarbon age scatter in LU-III contributes uncertainty regarding sediment age and hence the SRs and MARs derived for this interval as marked by the wider uncertainty band within the presented age model (Fig. 4b). Such age scatter may be in part associated with catchment glacial activity that could have led to the reworking of older catchment organic-containing sediments with subsequent deposition within the glaciolacustrine environment (cf. Lunkka et al., 2001). The usage of bulk sediment radiocarbon dating may additionally exacerbate this problem and add to radiocarbon uncertainty within LU-III as noted by Oswald et al. (2005) and others regarding dating of organic-poor, Last Glacial Maximum lacustrine sediments in Alaska and Siberia. Furthermore, the presence of layering within LU-III may also indicate potentially higher sedimentation rates across the unit (cf. Leemann and Niessen, 1994b). The lack of absolute dating of glacial structures within the Rauchua valley by Glushkova (2011), adds additional uncertainty regarding the temporal dynamics of the catchment glacier.

The temporally continuous, fine-grained, minerogenic sediment accumulation preserved within LU-III can likely be attributed regionally to the MIS2 Sartan glaciation recorded within Chukotka (Anderson and Lozhkin, 2015; BrighamGrette et al., 2003; Melles et al., 2012; Vyse et al., 2020) and the Itkillik II glaciation in Alaska, eastern Beringia (Hamilton and Ashley, 1993). Glaciation during this time was associated with asynchronous but early glacial advances in Alaskan mountain ranges between 31 and $28 \mathrm{kacal} \mathrm{BP}$ and advances in western Beringian glaciers to maximum extents between 27 and $20 \mathrm{kacal} \mathrm{BP}$ (Brigham-Grette et al., 2003; Elias and Brigham-Grette, 2013, and references therein). The presence of a valley glacier at Lake Rauchuagytgyn is in contrast to more westerly, eastern Russia sites from the Verkhoyansk Mountains where no glacial activity was witnessed during MIS2 (Diekmann et al., 2017; Stauch and Lehmkuhl, 2010). This supports previous suggestions that despite cold conditions, higher moisture derived from the Pacific Ocean permitted the existence of glaciers within Chukotka (Stauch and Gualtieri, 2008).

\subsubsection{Mid-MIS2-early MIS1 accumulation during progressive climate amelioration (ca. 23.4-11.69 ka cal BP)}

Sediment accumulation recorded by LU-II sediments represents a transitional mode between the early MIS2 and Holocene clearly viewed within PCA results between ca. 23.4 and $11.69 \mathrm{kacalBP}$ and likely reflects a timeprogressive shift towards the early stages of paraglacial deposition (Fig. 7). Hydroacoustic data show an upward transition to stable, deep water, lacustrine deposition represented by the increasing prevalence of stronger amplitudes from well-stratified reflectors (cf. Lebas et al., 2021; Haflidason et al., 2019). A clay maximum and grain-size minimum at ca. $550 \mathrm{~cm}$ (ca. $22.7 \mathrm{ka} \mathrm{cal} \mathrm{BP}$ ) may suggest initial increases in lake water depth through glacial melt additions that could have led to the observed reduced SRs and MARs at this time. This may be supported by the high values of $\mathrm{K} / \mathrm{Ti}$ (clay contribution) and low values of $\mathrm{Zr} / \mathrm{K}$ and $\mathrm{Si} / \mathrm{Al}$ (proxies for coarser grain sizes) (Kilian et al., 2013; Kříbek et al., 2017; Cuven et al., 2010). It is also likely that the persistence of the quasi-permanent ice layer continued to contribute to predominantly fine-grained, low energy deposition (Asikainen et al., 2007). The strong increase in $\mathrm{Zr} / \mathrm{K}$ accompanied by increased sand and silt contribution firstly at ca. $20.5 \mathrm{ka}$ cal BP consistent with a dramatic peak in SR and MAR values and again ca. $18.5 \mathrm{kacal}$ BP likely reflects increasingly rapid glacial retreat (Gromig et al., 2019). The timing of these system responses is generally consistent with depositional changes recorded at Lake Ilirney in response to deglaciation ca. $20 \mathrm{ka}$ (Vyse et al., 2020) and those proposed for Alaskan glacial retreat interpreted from dated moraine deposits and lacustrine sediments (20-19 ka BP)(Elias and Brigham-Grette, 2013; Finkenbinder et al., 2015, and references therein). Progressive deglaciation facilitated the gradual opening of the lake catchment area and development of fluvial systems that plausibly enhanced sediment load and input to the lake basin through the initiation of paraglacial processes (Ballantyne, 2002; Dedkov, 2004). Sediment dynamics were likely controlled by inflowing rivers at the lakes' southern margin as indicated by the greatest thicknesses of sediment within the southern sub-basin deposited within AU2 (Fig. 3c). Thick sediments within AU2 in the northern sub-basin may indicate additionally enhanced sedimentation derived from the north. The occurrence of a rhomboidalshaped deposit similar to preserved lake sediments within other lacustrine and continental shelf environments at the northern-shelf-northern-sub-basin transition may represent a mass transport deposit during some part of AU2 deposition (Figs. 2b, S5) (Baster et al., 2003). Catchment sediment availability likely also began to increase during this time due to gradual sub-aerial exposure of subglacial sediments that subsequently became entrained within paraglacial river systems or transported to the lake via aeolian processes con- 
tributing to progressively increasing sedimentation rates (Tripathi and Rajamani, 1999; Wang et al., 2015).

Organic carbon accumulation rates at the base of LU-II were slightly higher than LU-III, signifying increasing organic carbon production and accumulation across the LUIII-LU-II transition. Subsequently increasing rates alongside up-core sediment darkening and increases in all organic proxies across LU-II point towards continuous growth in carbon accumulation related to ameliorating conditions during the mid-MIS2-early MIS1 onwards. Organic productivity was most likely dominated by autochthonous productivity from within-lake algae with only minor contributions from catchment vegetation. Though nitrogen was not measured as part of this study, extremely low TOC/TN ratios measured for sediments at the nearby glacial Lake Ilirney during the late glacial implied that most organic matter was derived from protein-rich algal sources and not from cellulose-rich and protein-poor vascular land plants from the lake catchment and from macrophytes within the lake (Baumer et al., 2020; Meyers and Teranes, 2005; Vyse et al., 2020). This is supported by low pollen concentrations recorded within the Lake Ilirney pollen record and the persistence of Poaceae and Artemisia during the late glacial that signifies persistently cold conditions and low catchment pollen productivity (Andreev et al., 2021). Based on the similarities between the lakes and their catchments, their proximity, and a lack of macrophytes at both sites, a similar interpretation can be postulated for Lake Rauchuagytgyn (Sifeddine et al., 2011). Higher and more variable $\mathrm{Mn} / \mathrm{Fe}$ ratio values throughout much of LU-II point towards increased oxygen at the sediment-water interface that could have enhanced degradation of organic matter (Baumer et al., 2020; Fritz et al., 2018). This could be indicative of a gradually increasing summer open-water season with more intensive mixing of the water column through wind and also through enhanced fluvial inflow during progressive late glacial climate amelioration (Baumer et al., 2020).

A reduction in accumulation rates ca. 12.6 to ca. $11.69 \mathrm{kacalBP}$, broadly associated with a small reduction in sediment mean grain size, may represent some evidence of reduced accumulation due to cooling associated with the Younger Dryas (YD). The magnitude of this is, however, not substantial when all proxies are considered together within principal component analysis (Fig. 7). Moreover, missing evidence of younger moraines from the catchment implies that there was no glacial re-advance (Glushkova, 2011). These findings may be consistent with recent regional and trans-regional records that suggest a spatially variable Younger Dryas climatic event in east and Far East Russia and parts of eastern Beringia (Anderson and Lozhkin, 2015; Finkenbinder et al., 2015; Kokorowski et al., 2008b; Lozhkin and Anderson, 2013; Lozhkin et al., 2018). The lack of significant evidence for a strong Younger Dryas climatic event may also partially reflect seasonal differences in the sensitivity of physical and geochemical proxies to climatic or environmental change, as has been discussed in studies of sediment cores from Burial Lake, Alaska (Finkenbinder et al., 2015).

\subsubsection{Holocene controls on basin sediment and carbon dynamics (ca. 11.69 ka cal BP-present)}

The Holocene start is marked across all proxies by increasing organic proxy values and sediment grain size across the LUII-LU-I boundary (11.69 ka cal BP) alongside increasing accumulation rate values (Figs. 5, 6, 7). High TOC and TS and a dark sediment colour form a prominent peak during the Early Holocene between ca. 11.5 and $9.7 \mathrm{kacal} \mathrm{BP}$ synchronous with the lowest values of $\mathrm{Mn} / \mathrm{Fe}$ that could reflect increased preservation of organic material under low-oxygen conditions at the sediment-water interface alongside enhanced organic productivity (Fig. 6) (Fritz et al., 2018). Increasing carbon accumulation is supported by rising organic carbon accumulation rates that demonstrate high Early Holocene values between ca. 10.2 and 9.2 ka cal BP. Low K/Ti values during the Early Holocene that subsequently persist throughout the Middle-Late Holocene may reflect increased chemical relative to physical weathering due to the leaching of $\mathrm{K}$ from clastic material entering the lake by enhanced catchment pedogenic processes that influenced OCAR values as well as responding to coarser Holocene grain sizes (Baumer et al., 2020; D'Arcy and Carignan, 1997). The timing of this phase agrees well with the timing of warm and humid environments interpreted during the Early Holocene recorded at Lake Emanda, central Yakutia (11.5-9.0 ka cal BP), and coincides with the maximum in local solar insolation (Baumer et al., 2020; Berger and Loutre 1991). Moreover, this finding is consistent with palynological records from Lake Ilirney and from a Holocene short core from Lake Rauchuagytgyn, which show evidence for a local Holocene thermal maximum ca. 10.6-7 ka cal BP (Andreev et al., 2021).

Increasing Early Holocene sediment and mass accumulation rates alongside greater sand contribution may relate to the input of coarser-grained fluvial detrital material from a paraglacial, deglaciated catchment and could result from a water budget change associated with warmer and more humid conditions (Ballantyne, 2002). This is supported by increasing $\mathrm{Zr} / \mathrm{K}$ and $\mathrm{Si} / \mathrm{Al}$ ratio values during the Early Holocene that support coarser grain sizes that may relate to enhanced input of coarser silts and sands (cf. Píšková et al., 2019). It must, however, be noted that higher $\mathrm{Si} / \mathrm{Al}$ ratio values may also additionally reflect abundant diatoms within Holocene sediments (Procházka et al., 2019). Annual precipitation $\left(P_{\text {ann }}\right)$ reconstructed from palynological records at Lake Ilirney suggested an increase from ca. $225 \mathrm{~mm}$ during the late glacial to ca. $300 \mathrm{~mm}$ in the Early Holocene that could have enhanced catchment surface runoff and hence fluvially driven reworking of unstable-metastable glacially deposited sediment by paraglacial processes (Andreev et al., 2021; Ballantyne, 2002). Heinecke et al. (2017) proposed a 
similar scenario to explain increased Holocene sedimentation rates and increased grain sizes during the end of the late glacial and Early Holocene (13.3-6.6 ka cal BP) at glacial Lake Karakul. Moisture in north-eastern Siberia during interglacials is derived mostly from warm North Atlantic surface waters and brought via the westerlies to the region (Melles et al., 2007). The waning of the Scandinavian and Barents-Kara ice sheets likely allowed the passage of moister westerlies to the region that were blocked during the Last Glacial Maximum (Elias and Brigham-Grette, 2013; Meyer et al., 2002). Increased sedimentation rates also additionally enhanced carbon burial and preservation (Einsele et al., 2001). Enhanced precipitation and fluvial input to Lake Rauchuagytgyn during the Early Holocene could have led to lake-level increase and deep lacustrine conditions at the core location that restricted mixing of the water column, leading to stratification, and may provide a possible explanation for low-oxygen conditions (cf. Baumer et al., 2020). An increase in precipitation and rising lake levels was also interpreted for Early Holocene sediments preserved at Harding Lake, Alaska (Finkenbinder et al., 2014). Deep lacustrine conditions alongside enhanced Early Holocene within-lake and catchment productivity thus likely led to enhanced carbon deposition and preservation at Lake Rauchuagytgyn.

A decrease in TOC content (wt \%) to a minimum at ca. $8.6 \mathrm{kacal} \mathrm{BP}$ along with decreasing organic carbon and sediment and mass accumulation rates from $8.9 \mathrm{ka}$ cal BP to a minimum at ca. $7.7 \mathrm{ka} \mathrm{cal} \mathrm{BP}$ alongside finer grain sizes may reflect some local environmental change and is generally consistent with a Holocene $T_{\text {July }}$ minimum at $7.8 \mathrm{kacal} \mathrm{BP}$ and $P_{\text {ann }}$ minimum at $7.6 \mathrm{kacal} \mathrm{BP}$ recorded within a Lake Rauchuagytgyn short core (Andreev et al., 2021). This may possibly be associated with cooling associated generally with the $8.2 \mathrm{kacal} \mathrm{BP}$ event recorded at other locations within Siberia (Biskaborn et al., 2016). A degree of similarity between the TOC trend following the Early Holocene at both Lake Rauchuagytgyn and Lake Emanda may also suggest that bacterial sulfate reduction contributed to the reduced sedimentary organic carbon content during this interval (Fig. 6) (Baumer et al., 2020). A subsequent increase in OCARs from ca. $6.1 \mathrm{kacalBP}$ consistent with progressively increasing TOC values towards the modern lake sediment surface represents increased accumulation of organic carbon consistent with increasing mean July temperatures $\left(T_{\text {July }}\right)$ to a maximum ca. $13.3^{\circ} \mathrm{C}$ during the Middle-Late Holocene by ca. $4.6 \mathrm{kacal}$ BP (Andreev et al., 2021). Synchronous increases in SR and MAR along with coarser grain sizes may reflect extended periods of ice-free lake surface conditions during summer associated with high $T_{\text {July }}$ (Figs. 4, 5) (Finkenbinder et al., 2014). Extended open-water conditions during this time and throughout the Holocene likely led to longer phases of summer catchment aeolian input, as well as increased wind-driven shoreline erosion and sediment redistribution due to the impact of summer storms (Asikainen et al., 2007; Francke et al., 2013; Vologina et al., 2003).
This hypothesis is supported by the highest $\mathrm{Mn} / \mathrm{Fe}$ ratio values for the core, supportive of enhanced wind and fluvialdriven lake mixing processes and weaker stratification (Doran, 1993; Baumer et al., 2020; Regnéll et al., 2019). Francke et al. (2013) argued that coarser grain sizes and enhanced sedimentation at Lake El'gygytgyn during interglacials was controlled by summer temperatures affecting lake ice cover and hence aeolian input, wind-driven sediment redistribution, and catchment active layer thicknesses and water availability and was not affected by lake-level variations.

Decreasing accumulation rates from ca. $3.6 \mathrm{ka} \mathrm{cal} \mathrm{BP}$ to present could reflect reduced Late Holocene sediment input due to neoglacial cooling and is in line with variable $T_{\text {July }}$ and low $P_{\text {ann }}$ recorded within the Ilirney and Rauchuagytgyn short core records and generally lower Late Holocene $\mathrm{Mn} / \mathrm{Fe}$ ratio values (Fig. 6) (Andreev et al., 2021). This could tentatively be interpreted to represent a shortening of the summer open-water season.

Enhanced fluvial input to the lake basin throughout the Holocene from the Rauchua River valley and from the southeast lake margin are reflected in hydroacoustic and interpolated sediment thickness data (Fig. 3b) from AU1, which show greater thicknesses within the southern sub-basin. A similar distribution has been observed at glacial lakes Bolshoye Shchuchye and Levinson-Lessing (Haflidason et al., 2019; Lebas et al., 2019). The presence of an alluvial fan ca. $600 \mathrm{~m}$ in diameter at the south-eastern margin is supportive of intensified Holocene paraglacial processes that resulted in an input source of coarser fluvial and alluvial detrital material into the southern sub-basin contributing to the observed increased sedimentation and mass accumulation rates (cf. Doran, 1993; Smith and Jol, 1997). This is further supported by coarse, sand-dominated surface sediments close to the alluvial fan front (site EN18220) (Figs. 1 and S6, S7). Modern observations at Lake El'gygytgyn have shown that summer fluvial activation associated with snowmelt can lead to significant deposition of coarse material of cobble grade to the lake basin (Nolan and Brigham-Grette, 2007). Heightened availability of catchment sediment material due to thicker catchment active layer thicknesses during the Holocene may also provide an additional sediment source, leading to increased sedimentation. A thick tundra active layer present during the Holocene at Lake El'gygytgyn was suggested to have contributed to greater detrital input to the basin as well as promoting the weathering of clay minerals (Asikainen et al., 2007; Francke et al., 2013). This further supports the low $\mathrm{K} / \mathrm{Ti}$ ratios during the Holocene that evidence intensified chemical weathering (Regnéll et al., 2019). Acoustic reflectors preserved within AU1 generally reflect well-developed lacustrine deposition under deep-water conditions prevalent across the basin (Fig. 2) (Lebas et al., 2019). Some variability is observed within hydroacoustic data at the northern shelf where sediments are thin and evidence of erosion of sediments is seen (Fig. S2). This likely represents low deposition due to sediment transport into the deeper basin 
and feasibly some Holocene lake-level variability of several metres permitting localised erosion into shallow areas (Moernaut et al., 2010).

\subsection{Comparisons of carbon and sediment dynamics on a trans-regional scale}

\subsubsection{Organic carbon accumulation rates (OCARs)}

The calculated organic carbon accumulation rates for Lake Rauchuagytgyn represent the first calculated values for an Arctic Siberian glacial lake. As such, limited comparable studies exist and are restricted to studies of Siberian thermokarst lake systems that are generally younger and smaller (Anthony et al., 2014) and to the much larger Lake Baikal (Martin et al., 1998). Comparisons must therefore be additionally drawn to boreal and glacial lakes from North America and northern Europe, as well as to proglacial and bedrock-catchment lakes from Greenland. Significant differences, however, exist between these lake systems relating to contrasting environmental conditions prevailing at different latitudes as well as high variability with regards to lake and catchment spatial extent, lake water depth, and catchment environmental and vegetation properties.

The overall Holocene average organic carbon accumulation rate of $3.53 \mathrm{~g} \mathrm{OC} \mathrm{m}^{-2} \mathrm{a}^{-1}$ for Lake Rauchuagytgyn is significantly higher than those reported for the Pleistocene units represented by LU-II and LU-III (AU2) of $1.08 \mathrm{~g} \mathrm{OC} \mathrm{m}^{-2} \mathrm{a}^{-1}$ (Figs. 8, 9a). This is in accord with increased organic productivity, carbon accumulation, and generally higher SRs and MARs during the Holocene. The calculated Holocene rate is very similar to that obtained for Holocene deposits of boreal lakes from northern Quebec, Canada (mean $3.8 \mathrm{~g} \mathrm{OC} \mathrm{m}^{-2} \mathrm{a}^{-1}$ ), that were also studied using an equivocal hydroacoustic approach to account for sediment focussing and to rates obtained for Lake Baikal (mean $2.8 \mathrm{~g} \mathrm{OC} \mathrm{m}^{-2} \mathrm{a}^{-1}$ ) (Ferland et al., 2012, 2014; Martin et al., 1998) (Figs. 8, 9a). The range of Holocene rates is on average lower but generally overlaps with Holocene organic carbon accumulation rates of small $\left(0.033-0.73 \mathrm{~km}^{2}\right)$ Greenlandic lakes (mean $6 \mathrm{~g} \mathrm{OC} \mathrm{m}^{-2} \mathrm{a}^{-1}$ ) (Anderson et al., 2009) and small $\left(0.022-0.145 \mathrm{~km}^{2}\right)$ Uinta glacial lakes, USA (mean $5.4 \mathrm{~g} \mathrm{OC} \mathrm{m}^{-2} \mathrm{a}^{-1}$ ) (Munroe and Brencher, 2019). A strong resemblance is also observed when comparing to rates of accumulation calculated for Finnish boreal lakes that became ice-free at the Holocene start (Figs. 8, 9a, b) (Pajunen, 2000; Kortelainen et al., 2004). The average Holocene and whole core Rauchuagytgyn rates plot well within the range of Finnish lakes and close to the mean of shallow Quebec boreal lakes when considering sediment volumes derived from sub-bottom profiling approaches or estimated from core length and lake surface area (Uinta lakes) (Fig. 9a). Recent syntheses of average carbon accumulation rates within European lakes also suggest similar mean accumulation rates ca. 5.6 $\mathrm{g} \mathrm{OC} \mathrm{m}^{-2} \mathrm{a}^{-1}$ (Kastowski et al., 2011).
Pronounced differences exist when compared with larger lake systems reported from Alberta, Canada (mean $15 \mathrm{~g} \mathrm{OC} \mathrm{m}^{-2} \mathrm{a}^{-1}$ ) (Campbell et al., 2000), and global lakes, reservoirs and peatlands (Dean and Gorham, 1998; Mendonça et al., 2017). Furthermore, average Holocene rates calculated for thermokarst lakes from the CherskiiKolyma tundra, Far East Siberia, are markedly higher (mean $47 \mathrm{~g} \mathrm{OC} \mathrm{m}^{-2} \mathrm{a}^{-1}$ ) than Rauchuagytgyn rates (Anthony et al., 2014) (Fig. 8).

\subsubsection{Sediment and carbon pools within a Siberian Arctic glacial lake basin}

The total sediment pool of Rauchuagytgyn was estimated to $25.7 \pm 1.71 \mathrm{Mt}$ within a sediment volume of ca. $0.033 \mathrm{~km}^{3}$, with an average dry bulk sediment density of $780 \mathrm{~kg} \mathrm{~m}^{-3}$ $\left(0.780 \mathrm{~g} \mathrm{~cm}^{-3}\right)$. The sediment at Lake Rauchuagytgyn is predominantly inorganic as represented clearly by the very low total organic carbon content of sediments. The average calculated sediment density shows high agreement with global syntheses of sediment bulk density measured from lacustrine and fluvial sediments (Avnimelech et al., 2001; Haflidason et al., 2019; Munroe and Brencher, 2019; Sekellick et al., 2013). Sediment densities are, however, observed to be significantly higher than the average calculated for Holocene Finnish lakes $\left(0.25 \mathrm{~g} \mathrm{~cm}^{-3}\right)$ mostly due to greater organic carbon and water contents than those remarked for Rauchuagytgyn sediments (Pajunen, 2000).

The estimated $\mathrm{TOC}_{\text {pool }}$ (total ca. $0.26 \mathrm{Mt}$ ) and TOC density (total ca. $7.85 \mathrm{~kg} \mathrm{~m}^{-3}$ ) of Lake Rauchuagytgyn sediments presented here represent the first assessment of carbon pools within a Siberian Arctic glacial lake. Our results show that the sediment $\mathrm{TOC}_{\mathrm{pool}}$ and $\mathrm{TOC}$ density is relatively small, particularly during the deposition of LU-III and LUII that covers the Late Pleistocene and is in agreement with low OCARs discussed in Sect. 5.2.1. The small carbon pool is especially evident when compared with carbon budgets and sediment volumes reported for Pleistocene-Holocene age yedoma and thermokarst and drained thermokarst lake basin records from Alaska, as well as Holocene TOC $_{\text {pool }}$ and sediment volumes of Alberta glacial lakes, Canada (Fig. 9b) (Campbell et al., 2000; Jongejans et al., 2018). Pleistocene-Holocene sediments obtained from thermokarst lagoon and permafrost sediments from the Bykovsky Peninsula, northern Yakutia, also show significantly higher estimated $\mathrm{TOC}_{\text {pool }}$ (Bykovsky lagoons $5.72 \mathrm{Mt}$ ) and TOC density (mean $15.29 \mathrm{~kg} \mathrm{~m}^{-3}$ ) relative to their small spatial extents (Jenrich et al., 2021; Schirrmeister et al., 2011). Resemblance is, however, observed between the $\mathrm{TOC}_{\text {pool }}$ $(0.23 \mathrm{Mt})$ and TOC density $\left(12.54 \mathrm{~kg} \mathrm{~m}^{-3}\right)$ of the Polar Fox thermokarst lagoon (Bykovsky) and Rauchuagytgyn partic-

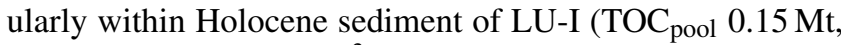
TOC density $9.87 \mathrm{~kg} \mathrm{~m}^{-3}$ ) (Jenrich et al., 2021). Moreover, similar values of $\mathrm{TOC}_{\mathrm{pool}}$ and TOC density relative to sediment volume have been estimated for Pleistocene-Holocene 


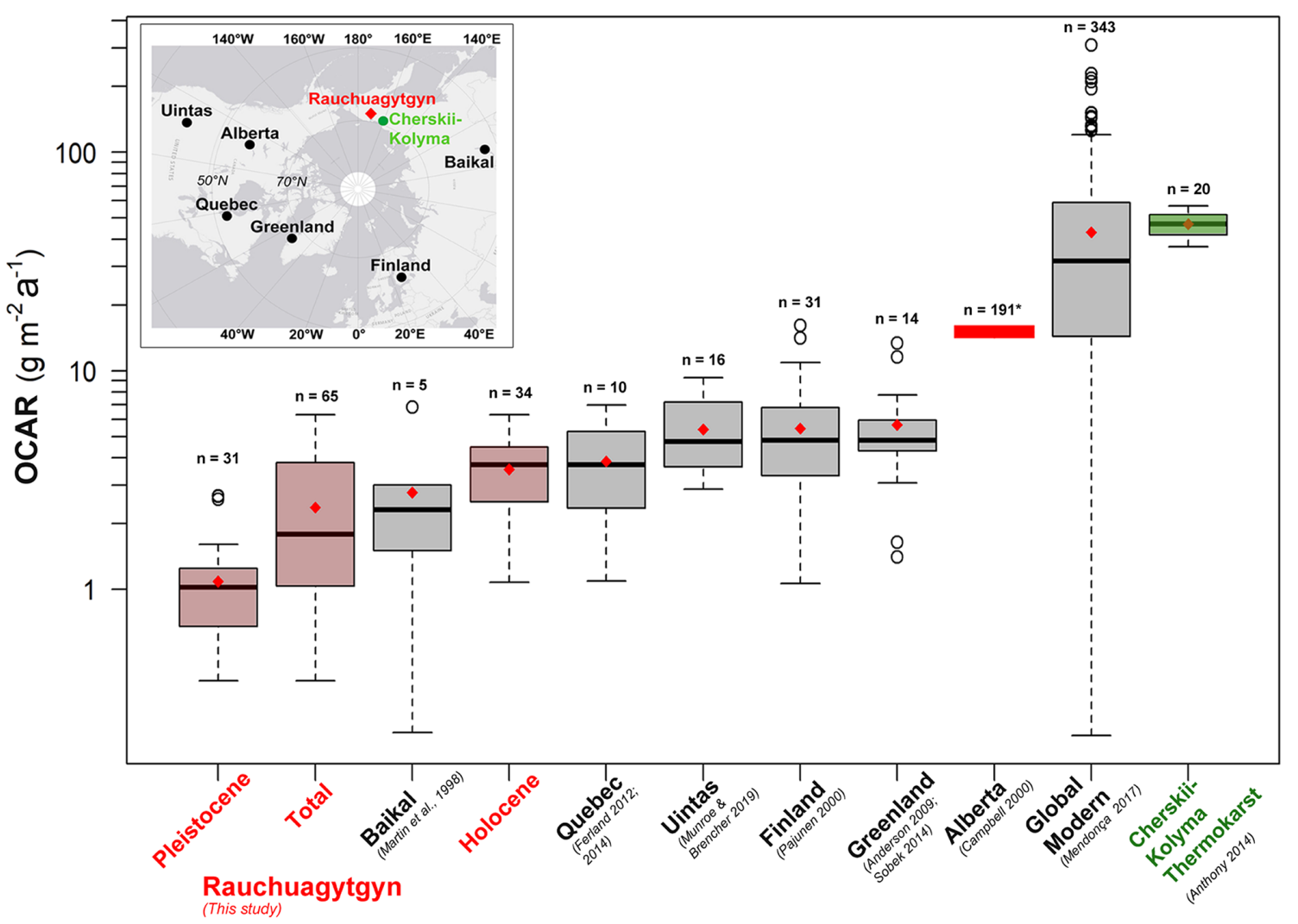

Figure 8. Comparison boxplot ( $y$ axis is log to the base 10 scaled) of average organic carbon accumulation rates (OCARs) for Lake Rauchuagytgyn with carbon accumulation rates from other regions. Rauchuagytgyn OCARs include a total of 65 down-core points and plot close to boreal lake sites and to Lake Baikal (ESRI 2020). The global modern dataset of Mendoça et al. (2017) included OCARs from 343 globally distributed lake sites (see Text S1). Only the average OCAR across Alberta lakes was provided in Campbell et al. (2000), and hence the average is displayed as a red bar. Study references are quoted below the study regions.

yedoma and alas sediments from central Yakutia, eastern Russia (yedoma: $0.057 \mathrm{Mt}, 5.27 \mathrm{~kg} \mathrm{~m}^{-3}$, alas: $0.032 \mathrm{Mt}$, $6.07 \mathrm{~kg} \mathrm{~m}^{-3}$ ), that are closer to the range of the Pleistocene values calculated at Rauchuagytgyn $\left(0.1 \mathrm{Mt}, 5.65 \mathrm{~kg} \mathrm{~m}^{-3}\right)$ (Windirsch et al., 2020). The highest degree of similarity is achieved with comparisons of $\mathrm{TOC}_{\mathrm{pool}}$, surface areas and sediment volumes to Finnish lakes, whereby Lake Rauchuagytgyn pools lie on a distinct trend in 3D logarithmic space within the range and around the mean of Finnish lakes (Fig. 9b) (Pajunen et al., 2000; Kortelainen et al., 2004). Estimated carbon pools from Uinta glacial lakes show markedly lower values that show they store significantly less carbon within their smaller sediment volume (Munroe and Brencher, 2019).

\subsubsection{Regional and local controls on carbon accumulation and methodological limitations}

Lake Rauchuagytgyn stores predominantly inorganic sediment detritus and demonstrates carbon dynamics not strongly dissimilar from other high-latitude lake systems. Differences are, however, revealed when comparisons of carbon dynam- ics are made to thermokarst and drained thermokarst lakes, large Alberta glacial lakes, and global lakes in general. The interplay between many varied factors likely contributes to major differences in carbon accumulation dynamics between different deposits and regions that are beyond a major discussion here and have been broadly considered elsewhere (Ferland et al., 2012; Kastowski et al., 2011; Sobek et al., 2009). Carbon accumulation at Lake Rauchuagytgyn is, however, likely affected by several key factors that can be identified.

Its mountainous, high-latitude, tundra location represents cold and dry environmental conditions that provide a firstorder climatic limit on catchment and lake internal primary productivity and hence carbon production. The expression of a cold climate is marked by open herb and graminoid tundra vegetation dominated by Poaceae and Dryas octopetala L. with the absence of vegetation at higher altitudes on lake proximal slopes and within the mountainous lake catchment (Shevtsova et al., 2020). The occurrence of a well-developed lake surface ice layer up to ca. $1.8 \mathrm{~m}$ in thickness that is present for ca. 9 months additionally contributes to reduced rates of algal primary productivity by limiting the availability of light as well as the allochthonous input of particulate or- 

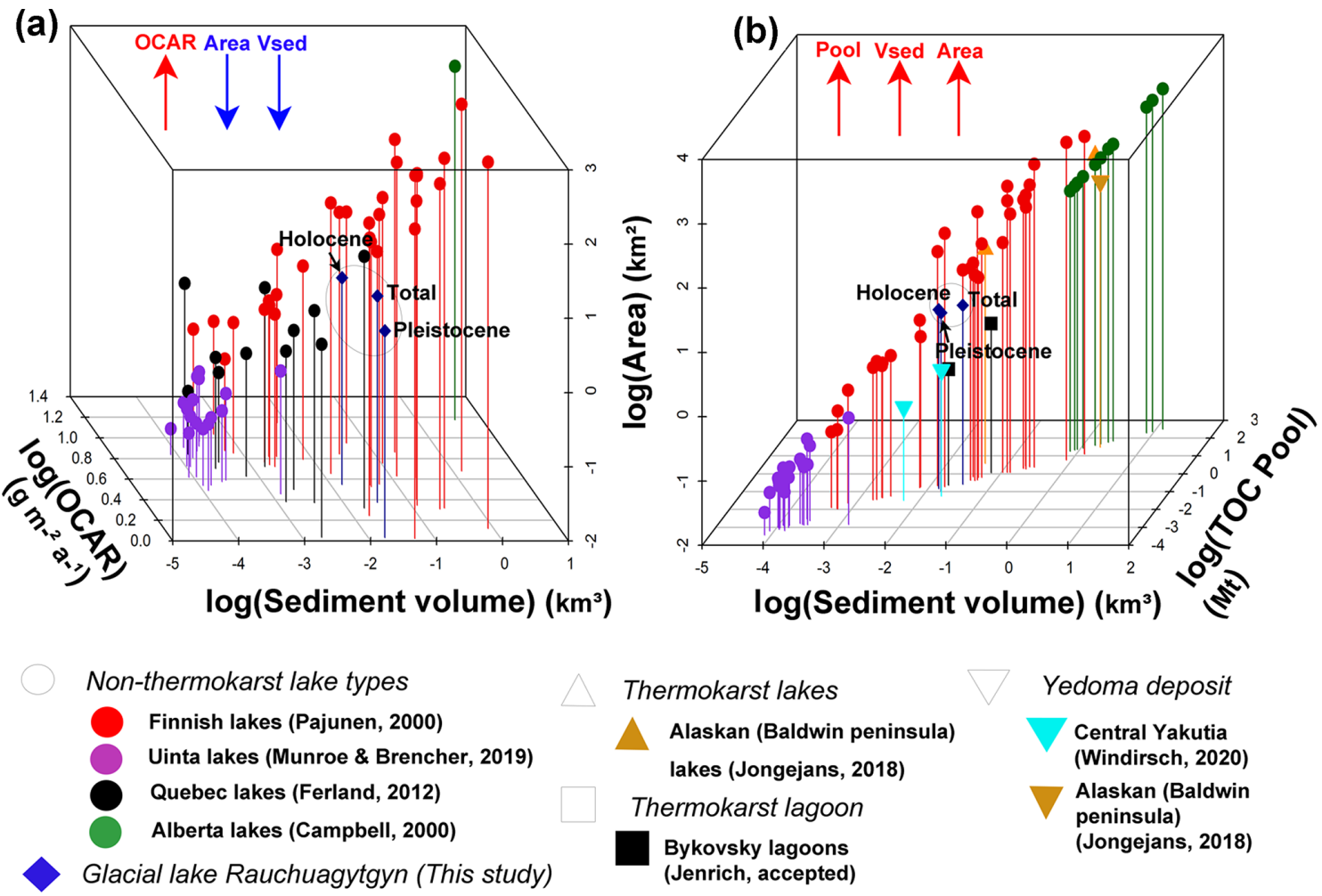

Figure 9. (a) Three-dimensional log scatter plot of organic carbon accumulation rate (OCAR) vs. lake sediment volumes and surface areas. The average carbon accumulation rate for the Holocene at Lake Rauchuagytgyn closely resembles that of Holocene age Finnish and Quebec lakes and generally lies on a trajectory of increasing OCAR with decreasing sediment volume and area. (b) Three-dimensional log scatter plot of carbon pool vs. sediment volume and area. The Rauchuagytgyn data points are highlighted with ellipses in both plots. Rauchuagytgyn displays similar carbon pools to Finnish lakes, Bykovsky thermokarst lagoons and central Yakutian yedoma deposits. Rauchuagytgyn sediments possess, however, significantly lower carbon pools relative to volume and area than Alaskan (Baldwin Peninsula) thermokarst lake and yedoma deposits and Alberta lakes.

ganic carbon (POC) and dissolved organic carbon (DOC) via fluvial and/or aeolian pathways (Baron et al., 1991; Nolan et al., 2002; Woolway and Merchant, 2019). An additional contributing factor to reduced catchment carbon export to Lake Rauchuagytgyn is likely connected to the steep, mountainous topography and poor soil development within the lake catchment. Catchment soil development is limited primarily to thin cryosols, but large areas of barren land exist at higher altitudes (Bünseler, 2019; Shevtsova et al., 2020). D'Arcy and Carignan (1997) suggested that lakes situated in steep catchments with thin soils demonstrate low DOC exports to lake systems that may lead to reduced carbon loading and hence reduced carbon accumulation. Low modern carbon export and production is supported by the extremely low DOC contents of lake surface water samples at Lake Rauchuagytgyn (Table S1) and at other regional lake sites (Huang et al., 2020) that support low organic matter export from the catchment (Bouchard et al., 2016). These factors were plausibly enhanced under more strongly continental, colder and drier Pleistocene climatic conditions that led to extremely low OCARs and a small carbon pool as evidenced by the multiple environmental proxies discussed throughout Sect. 5.1 (Fig. 9) (Anderson and Lozhkin, 2015; Einsele et al., 2001). Changes in sedimentation rates due to temporal variability in available moisture may also regulate the preservation of organic carbon within lacustrine sediments by affecting the time available for oxygen exposure and hence microbial degradation (Einsele et al., 2001). Higher Holocene sedimentation rates at Lake Rauchuagytgyn resulting from increased precipitation, active layer thickness and aeolian input may thus have further contributed to enhanced Holocene carbon accumulation. Lake area likely also plays a role in modulating differences in accumulation between lake sites and regions (Kastowski et al., 2011). Generally lakes of greater surface area possess lower rates of carbon accumulation due to reduced carbon loading (Ferland et al., 2012) (Fig. 9a). As geomorphic systems are hierarchical and operate at multiple spatio-temporal scales according to the concept of geomorphic connectivity, the diverse linkages and interrelationships between different catchment components and processes likely play a large and complex role in regulating sediment and carbon dynamics at Lake 
Rauchuagytgyn (Singh et al., 2021). Anthropogenic factors can also impact upon organic matter dynamics by changing the land use dynamics within lake catchments (Biskaborn et al., 2021). However, the current pristine nature of the Lake Rauchuagytgyn catchment and the low occurrence of human activity limit the anthropogenic influence when compared with lake catchments from more populous, lower-latitude regions (Kastowski et al., 2011). Nonetheless, the future impact of exploration and mining operations within the catchment and of climate change within the permafrost landscape could lead to future changes in sediment and carbon dynamics that are yet to be seen (Tranvik et al., 2009).

Differences in accumulation calculation and hence rates can also arise due to diverging methodological approaches that can lead to significant bias. The necessary usage of empirical equations to estimate sediment volumes (Campbell et al., 2000) owed to missing data or the simplification of sediment volumes to a box form by combining deposit thickness with area (Jongejans et al., 2018; Windirsch et al., 2020) can lead to the introduction of very large uncertainty regarding pool calculations. Volume uncertainty within our study has been minimised through the usage of hydroacoustic methods. Despite this, hydroacoustic methods can be limited to a lesser degree by acoustic blanking and hence data absence in some areas and difficulty in tracing sometimes poorly resolved reflectors. Further methodological uncertainty can arise through oversimplified estimation of dry bulk density (DBD) from empirical equations of DBD and carbon content where discrete, volumetric measurements do not exist (Avnimelech et al., 2001; Kastowski et al., 2011) as well as varied approaches used for the measurement of sample carbon contents (elemental analyser vs. loss on ignition (LOI)) (Munroe and Brencher, 2019). Limitations associated with radiocarbon dating of Arctic glacial lakes due to the absence of appreciable amounts of datable organic material, particularly during glacial phases as well as the reworking of old organic carbon present within catchment sediments that can be brought to the lake basin through permafrost and glacial processes during warm and cold phases respectively, can additionally lead to uncertainty with regards to sediment ages and hence reconstructed accumulation rates (Abbott and Stafford, 1996; Björck and Wohlfarth 2002; Oswald et al., 2005). Despite this, the calculated OCARs and pools for Lake Rauchuagytgyn are largely agreeable with multiple studies from northern regions and reinforce the reliability, applicability and novelty of the presented results.

\section{Conclusions}

This study aimed to improve the understanding of accumulation rates and pools within a palaeoenvironmental context of a Chukotkan Arctic glacial lake. The major outcomes are as follows.
- Sediment and carbon accumulation at Lake Rauchuagytgyn since MIS2 can be partitioned into three principal regimes (early MIS2, mid-MIS2-early MIS1 and Holocene accumulation) distinguished clearly from multiple environmental proxy records and calculated accumulation rates and pools.

- Early MIS2 accumulation (ca. 29-23.4 ka cal BP) was controlled by cold glacial-periglacial conditions, quasipermanent lake surface ice cover, the presence of a catchment glacier, and low sediment availability that led generally to low mass (MARs) and organic carbon accumulation rates (OCARs) and glacially derived minerogenic sediment deposition.

- Mid-MIS2-early MIS1 accumulation (ca. 23.4$11.69 \mathrm{ka}$ cal BP) likely reflects the increasing influence of paraglacial processes, longer surface ice-free summers, a thickening catchment active layer and increasing moisture availability. Carbon accumulation increased throughout and accompanied progressive climate amelioration.

- Holocene (ca. 11.69 ka cal BP-present) accumulation reflects a warmer and wetter climate with enhanced runoff within a deglaciated catchment that led to alluvial fan activation and enhanced catchment fluvial dynamics. Ice-free summers likely led to increased winddriven processes leading to more oxygenated lacustrine conditions during the Middle-Late Holocene and sediment redistribution. Higher Holocene OCARs reflect the prevailing climatic conditions and possibly the increased preservation under enhanced sedimentation rates.

- Estimated organic carbon pools reflect the presented accumulation regimes and demonstrate the larger carbon pool preserved within Holocene sediments $(0.15 \pm 0.005 \mathrm{Mt})$ when compared with Pleistocene sediments $(0.1 \pm 0.007 \mathrm{Mt})$. The carbon pool is, however, significantly small in comparison to the total sediment pool $(25.7 \pm 1.71 \mathrm{Mt})$.

- Carbon pools estimated for Finnish lake and Yakutian yedoma sediments show the greatest similarity to pools calculated for Lake Rauchuagytgyn sediments. Baldwin Peninsula (Alaska) permafrost landscapes and Alberta glacial lakes (Canada) represent larger organic carbon pools.

- Lake Rauchuagytgyn OCARs resemble estimations for Lake Baikal, as well as Finnish and Canadian boreal and proglacial and bedrock-catchment Greenlandic lakes. Estimated rates are, however, significantly lower than the global lake mean as well as Cherskii-Kolyma thermokarst lakes in Far East Russia. 
- The main drivers of OCAR and carbon pools on a temporal scale are likely related to palaeoclimate variations that control catchment and within-lake processes. Spatial differences with other lake systems are related to the high-latitude, mountainous setting of Lake Rauchuagytgyn.

Data availability. Data used in this study are accessible from the PANGAEA data repository https://doi.pangaea.de/10.1594/ PANGAEA.929719 (Vyse et al., 2021).

Supplement. The supplement related to this article is available online at: https://doi.org/10.5194/bg-18-4791-2021-supplement.

Author contributions. BKB and $\mathrm{UH}$ designed the study and together with LAP organised fieldwork. SAV obtained hydroacoustic profiling data and was responsible for opening, splicing and subsampling the core as well as all biogeochemical and sedimentological analyses. He also wrote the first version of the manuscript. GP was responsible for the age-depth model and sedimentation rates. NN provided magnetic susceptibility data. BKB supervised the works of SAV. BD assisted in the interpretation of hydroacoustic data. All co-authors contributed to the interpretation of the results and commented on the text.

Competing interests. The authors declare that they have no conflict of interest.

Disclaimer. Publisher's note: Copernicus Publications remains neutral with regard to jurisdictional claims in published maps and institutional affiliations.

Acknowledgements. We acknowledge funding from the Past Permafrost Project under the umbrella of the Earth System Knowledge Platform (ESKP) and the initiative and networking fund of the German Helmholtz Association. This research has been supported by the ERC European Union's Horizon 2020 research and innovation programme (grant agreement no. 772852, project GlacialLegacy) and the BMBF PALMOD (grant no. 01LP1510D) as well as the Russian Foundation for Basic Research (grant no. 18-45-140053) and the Ministry of Science and Higher Education of the Russian Federation (grant no. FSRG-2020-0019). The authors would like to thank all members that participated in the Chukotka 2018 expedition. We additionally thank Rebecca Morawietz, Jasmin Weise and Sebastian Golinski (AWI-Potsdam) for their assistance during laboratory work. The authors are grateful for the many helpful comments and suggestions made by Daniel Nývlt and one other anonymous reviewer as well as Petr Kuneš that helped to improve this paper.
Financial support. This research has been supported by the European Research Council H2020 (grant no. 772852), the Bundesministerium für Bildung und Forschung (grant no. 01LP1510D), the Russian Foundation for Basic Research (grant no. 18-45-140053), the Ministry of Science and Higher Education of the Russian Federation (grant no. FSRG-2020-0019), and the Past Permafrost Project under the umbrella of the Earth System Knowledge Platform (ESKP).

The article processing charges for this open-access publication were covered by the Alfred Wegener Institute, Helmholtz Centre for Polar and Marine Research (AWI).

Review statement. This paper was edited by Petr Kuneš and reviewed by Daniel Nyvlt and one anonymous referee.

\section{References}

Abbott, M. B. and Stafford Jr., T. W.: Radiocarbon Geochemistry of Modern and Ancient Arctic Lake Systems, Baffin Island, Canada, Quaternary Res., 45, 300-311, https://doi.org/10.1006/qres.1996.0031, 1996.

Adrian, R., O’Reilly, C. M., Zagarese, H., Baines, S. B., Hessen, D. O., Keller, W., Livingstone, D. M., Sommaruga, R., Straile, D., Van Donk, E., Weyhenmeyer, G. A., and Winder, M.: Lakes as sentinels of climate change, Limnol. Oceanogr., 54, 2283-2297, https://doi.org/10.4319/lo.2009.54.6_part_2.2283, 2009.

Andersen, D. W., Wharton Jr., R. A., and Squyres, S. W.: Terrigenous clastic sedimentation in Antarctic Dry Valley Lakes, Antarct Res. Ser., 59, 71-81, 1993.

Anderson, N. J., D'Andrea, W., and Fritz, S. C.: Holocene carbon burial by lakes in SW Greenland, Glob. Change Biol., 15, 25902598, https://doi.org/10.1111/j.1365-2486.2009.01942.x, 2009.

Anderson, P. M. and Lozhkin, A. V.: Late quaternary vegetation of Chukotka (northeast Russia) implications for glacial, and Holocene environments of Beringia, Quaternary Sci. Rev., 107, 112-128, https://doi.org/10.1016/j.quascirev.2014.10.016, 2015.

Andreev, A. A., Raschke, E., Biskaborn, B. K., Vyse, S. V., Courtin, J., Böhmer, T., Stoof-Leichsenring, K., Kruse, S., Pestryakova, L. A., and Herzschuh, U. H.: Late Pleistocene to Holocene vegetation, and climate changes in northwestern Chukotka (Far East Russia) deduced from lakes Ilirney, and Rauchuagytgyn pollen records, Boreas, 2021.

Anthony, K., Zimov, S., Grosse, G., Jones, M., Anthony, P., Chapin III, F., Finlay, J., Mack, M., Davydov, S., Frenzel P., and Frolking, S.: A shift of thermokarst lakes from carbon sources to sinks during the Holocene epoch, Nature, 511, 452-456, https://doi.org/10.1038/nature13560, 2014.

Arnaud, F., Révillon, S., Debret, M., Revel, M., Chapron, E., Jacob, J., Giguet-Covex, C., Poulenard, J., and Magny, M.: Lake Bourget regional erosion patterns reconstruction reveals Holocene NW European Alps soil evolution, and paleohydrology, Quaternary Sci. Rev., 51, 81-92, https://doi.org/10.1016/j.quascirev.2012.07.025, 2012.

Asikainen, C. A., Francus, P., and Brigham-Grette, J.: Sedimentology, clay mineralogy, and grain-size as indicators of $65 \mathrm{ka}$ of climate change from El'gygytgyn Crater 
Lake, Northeastern Siberia, J. Paleolimnol., 37, 105-122, https://doi.org/10.1007/s10933-006-9026-5, 2007.

Avnimelech, Y., Ritvo, G., Meijer, L., and Kochba, M.: Water content, organic carbon, and dry bulk density in flooded sediments, Aquac. Eng., 25, 25-33, 2001.

Bakke, J., Lie, øyvind, Nesje, A., Dahl, S. O., and Paasche, $\varnothing$.: Utilizing physical sediment variability in glacier-fed lakes for continuous glacier reconstructions during the Holocene, northern Folgefonna, western Norway, Holocene, 15, 161-176, https://doi.org/10.1191/0959683605hl797rp, 2005.

Ballantyne, C. K.: Paraglacial geomorphology, Quaternary Sci. Rev., 21, 18-19, 1935-2017, https://doi.org/10.1016/S02773791(02)00005-7, 2002.

Baron, J., McKnight, D., and Denning, A. S.: Sources of dissolved, and particulate organic material in Loch Vale Watershed, Rocky Mountain National Park, Colorado, USA, Biogeochemistry, 15, 89-110, https://doi.org/10.1007/BF00003219, 1991.

Baster, I., Girardclos, S., Pugin, A., and Wildi, W.: High-resolution seismic stratigraphy of an Holocene lacustrine delta in western Lake Geneva (Switzerland), in: Lake Systems from the Ice Age to Industrial Time, edited by: Ariztegui, D. and Wildi, W., Eclogae Geologicae Helvetiae, Swiss J. Geosci., Vol. 1, Birkhäuser, Basel, https://doi.org/10.1007/978-3-0348-7992-7_3, 2003.

Battin, T. J., S. Luyssaert, L. A. Kaplan, A. K. Aufdenkempe, A. Richter, L. J., and Tranvik, L. J.: The boundless carbon cycle, Nat. Geosci., 2, 598-600, https://https://doi.org/10.1038/ngeo618, 2009.

Baumer, M. M., Wagner, B., Meyer, H., Leicher, N., Lenz, M., Fedorov, G., Pestryakova, L. A., and Melles, M.: Climatic, and environmental changes in the Yana Highlands of northeastern Siberia over the last c. 57000 years, derived from a sediment core from Lake Emanda, Boreas, 50, 114-133, https://doi.org/10.1111/bor.12476, 2020.

Berger, A. and Loutre, M. F.: Insolation values for the climate of the last 10 million years, Quaternary Sci. Rev., 10, 297-317, 1991.

Birks, H. H. and Birks, H. J. B.: Multi-proxy studies in palaeolimnology, Veget. Hist. Archaeobot., 15, 235-251, https://doi.org/10.1007/s00334-006-0066-6, 2006.

Biskaborn, B. K., Herzschuh, U., Bolshiyanov, D., Savelieva, L., and Diekmann, B.: Environmental variability in northeastern Siberia during the last $\sim 13300 \mathrm{yr}$ inferred from lake diatoms, and sediment-geochemical parameters, Palaeogeogr. Palaeocl., 329/330, 22-36, https://doi.org/10.1016/j.palaeo.2012.02.003, 2012.

Biskaborn, B. K., Herzschuh, U., Bolshiyanov, D. Y., Schwamborn, G., and Diekmann, B.: Thermokarst processes, and depositional events in a tundra lake, northeastern Siberia, Permafr. Periglac. Process., 24, 160-174, https://doi.org/10.1002/ppp.1769, 2013.

Biskaborn, B. K, Subetto, D., Savelieva, L,. Vakhrameeva, P., Hansche, A., Herzschuh, U., Klemm, J., Heinecke, L., Pestryakova, L., Meyer, H., Kuhn, G., and Diekmann, B.: Late Quaternary vegetation, and lake system dynamics in north-eastern Siberia: Implications for seasonal climate variability, Quaternary Sci. Rev., 147, 406-421, https://doi.org/10.1016/j.quascirev.2015.08.014, 2016.

Biskaborn, B. K., Nazarova, L., Pestryakova, L. A., Syrykh, L., Funck, K., Meyer, H., Chapligin, B., Vyse, S., Gorodnichev, R., Zakharov, E., Wang, R., Schwamborn, G., Bailey, H. L., and Diekmann, B.: Spatial distribution of environmental indicators in surface sediments of Lake Bolshoe Toko, Yakutia, Russia, Biogeosciences, 16, 4023-4049, https://doi.org/10.5194/bg-164023-2019, 2019.

Biskaborn, B. K., Narancic, B., Stoof-Leichsenring, K. R., Pestryakova, L. A., Appleby, P. G., Piliposian, G. T., and Diekmann, B.: Effects of climate change, and industrialization on Lake Bolshoe Toko, eastern Siberia, J. Paleolimnol., 65, 335352, https://doi.org/10.1007/s10933-021-00175-z, 2021.

Björck, S. and Wohlfarth, B.: ${ }^{14} \mathrm{C}$ chronostratigraphic techniques in paleolimnology, in: Tracking environmental change using lake sediments, Basin Analysis, Coring, and Chronological Techniques, edited by: Last, W. M. and Smol, J. P., Springer, Dordrecht, the Netherlands, 205-245, 2002.

Blott, S. J. and Pye, K.: GRADISTAT: A grain size distribution, and statistics package for the analysis of unconsolidated sediments, Earth Surf. Proc. Land., 26, 1237-1248, https://doi.org/10.1002/esp.261, 2001.

Bouchard, F., Francus, P., Pienitz, R., and Laurion, I.: Sedimentology, and geochemistry of thermokarst ponds in discontinuous permafrost, subarctic Quebec, Canada, J. Geophys. Res., 116, G00M04, https://https://doi.org/10.1029/2011JG001675, 2011.

Bouchard, F., MacDonald, L. A., Turner, K. W., Thienpont, J. R., Medeiros, A. S., Biskaborn, B. K., Korosi, J., Hall, R. I., Pienitz, R., and Wolfe, B. B.: Paleolimnology of thermokarst lakes: a window into permafrost landscape evolution, Arctic Sci., 3, 91117, https://doi.org/10.1139/as-2016-0022, 2016.

Brigham-Grette, J., Gualtieri, L. M., Glushkova, O. Y., Hamilton, T. D., Mostoller, D., and Kotov, A.: Chlorine-36, and ${ }^{14} \mathrm{C}$ chronology support a limited last glacial maximum across central Chukotka, northeastern Siberia, and no Beringian ice sheet, Quaternary Res., 59, 386-398, https://doi.org/10.1016/S00335894(03)00058-9, 2003.

Brosius, L. S., Walter Anthony, K. M., Treat, C. C., Lenz, J., Jones, M. C., Bret-Harte, M. S., and Grosse, G.: Spatiotemporal patterns of northern lake formation since the Last Glacial Maximum, Quaternary Sci. Rev., 253, 106773, https://doi.org/10.1016/j.quascirev.2020.106773, 2021.

Bünseler, L.: Interaction of active layer carbon, and nitrogen content with vegetation types on a tundra to taiga transect in eastern Siberia, MSc thesis, Potsdam University, Potsdam, Germany, 2019.

Campbell, I. D., Campbell, C., Vitt, D. H., Kelker, D., Laird, L. D., Trew, D., Kotak, B., LeClair, D., and Bayley, S.: A first estimate of organic carbon storage in Holocene lake sediments in Alberta, Canada, J. Paleolimnol., 24, 395-400, https://https://doi.org/10.1023/A:1008103605817, 2000.

Canty, A. and Ripley, B. D.: boot: Bootstrap R (S-Plus) Functions, R package version 1.3-26, 2020.

Cole, J. J., Prairie, Y. T., Caraco, N. F., McDowell, W. H., Tranvik, L. J., Striegl, R. G., Duarte, C. M., Kortelainen, P., Downing, J. A., Middelburg J. J., and Melack, J.: Plumbing the global carbon cycle: Integrating inland waters into the terrestrial carbon pool, Ecosystems, 10, 172-185, https://https://doi.org/10.1007/s10021-006-9013-8, 2007.

Cremer, H. and Wagner, B.: The diatom flora in the ultraoligotrophic Lake El'gygytgyn, Chukotka, Polar Biol., 26, 105114, https://doi.org/10.1007/s00300-002-0445-0, 2003.

Croudace, I. W. and Rothwell, R. G. (Eds.): Micro-XRF Studies of Sediment Cores: Applications of a non-destructive tool for 
the environmental sciences, Springer, the Netherlands, $656 \mathrm{pp}$., https://doi.org/10.1007/978-94-017-9849-5, 2015.

Cuven, S., Francus, P., and Lamoureux, S. F.: Estimation of grain size variability with micro $\mathrm{X}$-ray fluorescence in laminated lacustrine sediments, Cape Bounty, Canadian High Arctic, J. Paleolimnol., 44, 803-817, https://doi.org/10.1007/s10933-0109453-1, 2010.

D'Arcy, P. and Carignan, R.: Influence of catchment topography on water chemistry in southeastern Québec shield lakes, Can. J. Fish. Aquat. Sci., 54, 2215-2227, https://https://doi.org/10.1139/f97-129, 1997.

Davison, A. C. and Hinkley, D. V. (Eds.): Bootstrap Methods, and Their Applications, Cambridge University Press, Cambridge, available at: http://statwww.epfl.ch/davison/BMA/ (last access: 19 August 2021), 1997.

Dean, W. E. and Gorham, E.: Magnitude, and significance of carbon burial in lakes, reservoirs, and peatlands, Geology, 26, 535-538, 1998.

Dedkov, A.: The relationship between sediment yield, and drainage basin area. Sediment Transfer through the Fluvial System (Proceedings of a symposium held in Moscow. August 2004), IAHS Publ., 288, 197-204, 2004.

Diekmann, B., Pestryakova, L., Nazarova, L., Subetto, D., Tarasov, P., Stauch, G., Thiemann, A., Lehmkuhl, F., Biskaborn, B., Kuhn, G., Henning, D., and Müller, S.: Late Quaternary lake dynamics in the Verkhoyansk Mountains of eastern Siberia: Implications for climate, and glaciation history, Polarforschung, 86, 97-110, https://doi.org/10.2312/polarforschung.86.2.97, 2016.

Dietze, E., Maussion, F., Ahlborn, M., Diekmann, B., Hartmann, K., Henkel, K., Kasper, T., Lockot, G., Opitz, S., and Haberzettl, T.: Sediment transport processes across the Tibetan Plateau inferred from robust grain-size end members in lake sediments, Clim. Past, 10, 91-106, https://doi.org/10.5194/cp-10-91-2014, 2014

Doran, P. T.: Sedimentology of Colour Lake, a Nonglacial High Arctic Lake, Axel Heiberg Island, N. W. T., Canada, Arct. Alp. Res., 25, 353-367, https://doi.org/10.1080/00040851.1993.12003021, 1993.

Einola, E., Rantakari, M., Kankaala, P., Kortelainen, P., Ojala, A., Pajunen, H., Mäkelä, S., and Arvola, L.: Carbon pools, and fluxes in a chain of five boreal lakes: A dry, and wet year comparison, J. Geophys. Res., 116, G03009, https://doi.org/10.1029/2010JG001636, 2011.

Einsele, G., Yan, J. P., and Hinderer, M.: Atmospheric carbon burial in modern lake basins, and its significance for the global carbon budget, Glob. Planet. Change, 30, 167-195, https://https://doi.org/10.1016/S0921-8181(01)00105-9, 2001.

Elias, S. A. and Brigham-Grette, J.: Glaciations: Late Pleistocene glacial events in Beringia, in: Encyclopedia of Quaternary Science, edited by: Elias, S. A., Elsevier, Amsterdam, 191-201, 2013.

Ferland, M. E., del Giorgio, P. A., Teodoru, C. R., and Prairie, Y. T.: Long-term $\mathrm{C}$ accumulation, and total $\mathrm{C}$ stocks in boreal lakes in northern Québec, Global Biogeochem. Cy., 26, GB0E04, https://doi.org/10.1029/2011GB004241, 2012.

Ferland, M. E., Prairie, Y. T., Teodoru, C., and del Giorgio, P. A.: Linking organic carbon sedimentation, burial efficiency, and long-term accumulation in boreal lakes, J. Geophys. Res.-
Biogeo., 119, 836-847, https://doi.org/10.1002/2013JG002345, 2014.

Finkenbinder, M. S., Abbott, M. B., Edwards, M. E., Langdon, C. T., Steinman, B. A., and Finney, B. P.: A 31,000 year record of paleoenvironmental, and lake-level change from Harding Lake, Alaska, USA, Quaternary Sci. Rev., 87, 98-113, https://doi.org/10.1016/j.quascirev.2014.01.005, 2014.

Finkenbinder, M. S., Abbott, M. B., Finney, B. P., Stoner, J. S., and Dorfman, J. M.: A multi-proxy reconstruction of environmental change spanning the last 37,000 years from Burial Lake, Arctic Alaska, Quaternary Sci. Rev, 126, 227-241, https://doi.org/10.1016/j.quascirev.2015.08.031, 2015.

Folk, R. L. and Ward, W. C.: Brazos River bar [Texas]; a study in the significance of grain size parameters, J. Sediment. Res., 27, 3-26, https://doi.org/10.1306/74D70646-2B21-11D78648000102C1865D, 1957.

Francke, A., Wennrich, V., Sauerbrey, M., Juschus, O., Melles, M., and Brigham-Grette, J.: Multivariate statistic, and time series analyses of grain-size data in quaternary sediments of Lake El'gygytgyn, NE Russia, Clim. Past, 9, 2459-2470, https://doi.org/10.5194/cp-9-2459-2013, 2013.

Friedman, G. M. and Sanders, J. E. (Eds.): Principles of Sedimentology, Wiley, New York, 1978.

Fritz, M., Unkel, I., Lenz, J., Gajewski, K., Frenzel, P., Paquette, N., Lantuit, H., Körte, L., and Wetterich, S.: Regional environmental change versus local signal preservation in Holocene thermokarst lake sediments: A case study from Herschel Island, Yukon (Canada), J. Paleolimnol., 60, 77-96, https://doi.org/10.1007/s10933-018-0025-0, 2018.

Gentz, T., Bonk, E., Hefter, J., Grotheer, H., Meyer, V., and Mollenhauer, G.: Establishment of routine sample preparation protocols at the newly installed MICADAS ${ }^{14} \mathrm{C}$ dating facility at AWI, AMS 14 Conference, Ottawa, 14-18 August 2017, 2017.

Glushkova, O. Y.: Chap. 63: Late Pleistocene Glaciations in NorthEast Asia, in: Developments in Quaternary Sciences, edited by: Ehlers, J., Gibbard, P. L., and Hughes, P. D., Elsevier, Amsterdam, 865-875, https://doi.org/10.1016/B978-0-444-534477.00063-5, 2011.

Gromig, R., Wagner, B., Wennrich, V., Fedorov, G., Savelieva, L., Lebas, E., Krastel, S., Brill, D., Andreev, A., Subetto, D., and Melles, M.: Deglaciation history of Lake Ladoga (northwestern Russia) based on varved sediments, Boreas, 48, 330-348, https://doi.org/10.1111/bor.12379, 2019.

Gurnell, A., Hannah, D., and Lawler, D: Suspended sediment yield from glacier basins, Erosion, and Sediment Yield: Global, and Regional Perspectives, Proceedings of the Exeter Symposium, July, 1996.

Haflidason, H., Zweidorff, J. L., Baumer, M., Gyllencreutz, R., Svendsen, J. I., Gladysh, V., and Logvina, E.: The Lastglacial, and Holocene seismostratigraphy, and sediment distribution of Lake Bolshoye Shchuchye, Polar Ural Mountains, Arctic Russia, Boreas, 48, 452-469, https://doi.org/10.1111/bor.12387, 2019.

Hamilton, T. and Ashley, G.: Epiguruk: a late Quaternary environmental record from northwestern Alaska, GSA Bull., 105, 583-602, https://doi.org/10.1130/00167606(1993)105<0583:ealqer>2.3.co;2, 1993.

Heinecke, H., Mischke, S., Adler, S., Barth, A., Biskaborn, B. K., Plessen, B., Nitze, I., Kuhn, G., Rajabov, I., and Herzschuh, U.: Climatic, and limnological changes at Lake Karakul (Tajik- 
istan) during the last $\sim 29$ cal ka, J. Paleolimnol., 58, 317-334, https://doi.org/10.1007/s10933-017-9980-0, 2017.

Hinderer, M. and Einsele, G.: The world's large lake basins as denudation-accumulation systems, and implications for their lifetimes, J. Paleolimnol., 26, 355-372, https://doi.org/10.1023/A:1012651232541, 2001.

Huang, S., Herzschuh, U., Pestryakova, L. A., Zimmermann, H. H., Davydova, P., Biskaborn, B. K., Shevtsova, I., and StoofLeichsenring, K. R.: Genetic and morphologic determination of diatom community composition in surface sediments from glacial, and thermokarst lakes in the Siberian Arctic, J. Paleolimnol., 64, 225-242, https://doi.org/10.1007/s10933-020-00133-1, 2020.

Jenrich, M., Angelopoulos, M., Grosse, G., Overduin, P.P., Schirrmeister, L., Nitze, I., Biskaborn, B.K., Liebner, S., Grigoriev, M., Murray, A., and Strauss, J.: Thermokarst Lagoons on Bykovsky Peninsula: A Core-Based Assessment of Depositional Characteristics, and Estimate of Carbon Pools, Front. Earth Sci., 9, 518, https://doi.org/10.3389/feart.2021.637899, 2021.

Jongejans, L., Strauss, J., Lenz, J., Peterse, F., Mangelsdorf, K., Fuchs, M., and Grosse, G.: Organic matter characteristics in Yedoma, and thermokarst deposits on Baldwin Peninsula, west Alaska, Biogeosciences, 15, 6033-6048, https://doi.org/10.5194/bg-15-6033-2018, 2018.

Jongejans, L. and Strauss, J.: Bootstrapping approach for permafrost organic carbon pool estimation, Zenodo, https://doi.org/10.5281/zenodo.3734247, 2020.

Karlen, W. and Matthews, J. A.: Reconstructing Holocene Glacier Variations from Glacial Lake Sediments: Studies from Nordvestlandet, and Jostedalsbreen-Jotunheimen, Southern Norway, Geografiska Annaler, Series A, Phys. Geogr., 74, 327-348, 1992.

Kastowski, M., Hinderer, M., and Vecsei, A.: Longterm carbon burial in European lakes: Analysis, and estimate, Global Biogeochem. Cy., 25, GB3019, http://https://doi.org/10.1029/2010GB003874, 2011.

Kilian, R., Baeza, O., Breuer, S., Ríos, F., Arz, H., Lamy, F., Wirtz, J., Baque, D., Korf, P., Kremer, K., Ríos, C., Mutschke, E., Simon, M., De Pol-Holz, R., Arevalo, M., Wörner, G., Schneider, C., and Casassa, G.: Late Glacial, and Holocene Paleogeographical, and Paleoecological Evolution of the Seno Skyring, and Otway Fjord Systems in the Magellan Region, Anales Instituto Patagonia (Chile), 41, 5-26, https://doi.org/10.4067/S0718686X2013000200001, 2013.

Kokorowski, H. D., Anderson, P. M., Sletten, R. S., Lozhkin, A. V., and Brown T. A.: Late Glacial, and Early Holocene Climatic Changes Based on a Multiproxy Lacustrine Sediment Record from Northeast Siberia, Arct. Antarct. Alp. Res., 40, 497-505, 2008 .

Kokorowski, H. D., Anderson, P. M., Mock, C. J., and Lozhkin, A. $\mathrm{V}$.: A re-evaluation and spatial analysis of evidence for a Younger Dryas climatic reversal in Beringia, Quaternary Sci. Rev., 27, 1710-1722, https://doi.org/10.1016/j.quascirev.2008.06.010, 2008b.

Kortelainen, P., Pajunen, H., Rantakari, M., and Saarnisto M.: A large carbon pool, and small sink in boreal Holocene lake sediments, Global Change Biol., 10, 1648-1653, https://https://doi.org/10.1111/j.1365-2486.2004.00848.x, 2004.
Kříbek, B., Knésl, I., Rojík, P., Sýkorová, I., and Martínek, K.: Geochemical history of a Lower Miocene lake, the Cypris Formation, Sokolov Basin, Czech Republic, J. Paleolimnol., 58, 169-190, https://doi.org/10.1007/s10933-017-9970-2, 2017.

Lebas, E., Krastel, S., Wagner, B., Gromig, R., Fedorov, G., Baumer, M., Kostromina, N., and Haflidason, H.: Seismic stratigraphical record of Lake Levinson-Lessing, Tayma Peninsula: evidence for ice-sheet dynamics, and lake-level fluctuations since the Early Weichselian, Boreas, 48, 470-487, https://doi.org/10.1111/bor.12381, 2019.

Lebas, E., Gromig, R., Krastel, S., Wagner, B., Fedorov, G., Görtz, C., Averes, T., Subetto, D., Naumenko, M., and Melles, M.: Preglacial, and post-glacial history of the Scandinavian Ice Sheet in NW Russia - Evidence from Lake Ladoga, Quaternary Sci. Rev., 251, 106637, https://doi.org/10.1016/j.quascirev.2020.106637, 2021.

Leemann, A. and Niessen, F.: Holocene glacial activity, and climatic variations in the Swiss Alps: reconstructing a continuous record from proglacial lake sediments, Holocene, 4, 259-268, https://doi.org/10.1177/095968369400400305, 1994b.

Lehman, J. T.: Reconstructing the rate of accumulation of lake sediment: Their effect of sediment focusing, Quaternary Res., 5,541-550, https://https://doi.org/10.1016/00335894(75)90015-0, 1975.

Lenz, M., Savelieva, L., Frolova, L., Cherezova, A., Moros, M., Baumer, M. M., Gromig, R., Kostromina, N., Nigmatullin, N., Kolka, V., Wagner, B., Fedorov, G., and Melles, M.: Lateglacial, and Holocene environmental history of the central Kola region, northwestern Russia revealed by a sediment succession from Lake Imandra, Boreas, 50, 76-100, https://doi.org/10.1111/bor.12465, 2020.

Lougheed, B. C. and Obrochta, S. P.: A Rapid, Deterministic AgeDepth Modeling Routine for Geological Sequences With Inherent Depth Uncertainty, Paleoceanogr. Paleoclimatol., 34, 122 133, https://doi.org/10.1029/2018PA003457, 2019.

Lozhkin, A. V. and Anderson, P. M.: Late quaternary lake records from the Anadyr lowland, central Chukotka (Russia), Quaternary Sci. Rev., 68, 1-16, https://doi.org/10.1016/j.quascirev.2013.02.007, 2013.

Lozhkin, A. V., Brown, T. A., Anderson, P. M., Glushkova, O. Y., and Melekestsev, I. V.: The importance of radiocarbon dates, and tephra for developing chronologies of Holocene environmental changes from lake sediments, North Far East, Russ. J. Pac. Geol., 10, 249-262, https://doi.org/10.1134/S1819714016040047, 2016.

Lozhkin, A. V., Anderson, P. M., Minyuk, P., Korzun, J., Brown, T., Pakhomov, A., Tsygankova, V., Burnatny, S., and Naumov, A.: Implications for conifer glacial refugia, and postglacial climatic variation in western Beringia from lake sediments of the Upper Indigirka basin, Boreas, 47, 938-953, https://doi.org/10.1111/bor.12316, 2018.

Lunkka, J. P., Saarnisto, M., Gey, V., Demidov, I., and Kiselova, V.: Extent, and age of the Last Glacial Maximum in the southeastern sector of the Scandinavian Ice Sheet, Glob. Planet. Change, 31, 407-425, https://doi.org/10.1016/S0921-8181(01)00132-1, 2001.

Marshall, M. H., Lamb, H. F., Huws, D., Davies, S. J., Bates, R., Bloemendal, J., Boyle, J., Leng, M. J., Umer, M., and Bryant, C.: Late Pleistocene, and Holocene drought events at Lake Tana, 
the source of the Blue Nile, Glob. Planet. Change, 78, 147-161, https://doi.org/10.1016/j.gloplacha.2011.06.004, 2011.

Martin, P., Granina, L., Martens, K., and Goddeeris, B.: Oxygen concentration profiles in sediments of two ancientlakes: Lake Baikal (Siberia, Russia), and Lake Malawi (EastAfrica), Hydrobiologia, 367, 163-174, https://doi.org/10.1023/A:1003280101128, 1998.

McLaren, P. and Bowles, D.: The effects of sediment transport on grain-size distributions, Int. J. Sediment Res., 55, 457-470, https://doi.org/10.1306/212F86FC-2B24-11D7$8648000102 \mathrm{C} 1865 \mathrm{D}, 1985$

Melles, M., Brigham-Grette, J., Glushkova, O. Y., Minyuk, P. S., Nowaczyk, N. R., and Hubberten, H. W.: Sedimentary geochemistry of core PG1351 from Lake El'gygytgyn-a sensitive record of climate variability in the East Siberian Arctic during the past three glacial-interglacial cycles, J. Paleolimnol., 37, 89-104, https://doi.org/10.1007/s10933-006-9025-6, 2007.

Melles, M., Brigham-Grette, J., Minyuk, P. S., Nowaczyk, N. R., Wennrich, V., DeConto, R. M., Anderson, P. M., Andreev, A. A., Coletti, A., Cook, T. L., Haltia-Hovi, E., Kukkonen, M., Lozhkin, A. V., Rosén, P., Tarasov, P., Vogel, H., and Wagner, B.: 2.8 Million years of arctic climate change from Lake El'gygytgyn, NE Russia, Science, 337, 315-320, https://doi.org/10.1126/science.1222135, 2012.

Mendonça, R., Müller, R. A., Clow, D., Verpoorter, C., Raymond, P., Tranvik, L. J., and Sobek, S.: Organic carbon burial in global lakes, and reservoirs, Nat. Commun., 8, 1694, https://doi.org/10.1038/s41467-017-01789-6, 2017.

Menne, M. J., Durre, I., Korzeniewski, B., McNeal, S., Thomas, K., Yin, X., Anthony, S., Ray, R., Vose, R. S., Gleason, B. E., and Houston, T. G.: Global Historical Climatology Network - Daily (GHCN-Daily), Version 3 NOAA National Climatic Data Center, https://https://doi.org/10.7289/V5D21VHZ, 2012.

Meyer, H., Derevyagin, A. Y., Siegert, C., and Hubberten, H. W.: Paleoclimate studies on Bykovsky Peninsula, North Siberiahydrogen, and oxygen isotopes in ground ice, Polarforschung, 70, 37-51, 2002.

Meyers, P. A. and Teranes, J. L.: Sediment organic matter, In: Tracking Environmental Change Using Lake Sediments, edited by Smol, J., Kluwer Academic Publishers, Dordrecht, 239-269, https://doi.org/10.1007/0-306-47670-3_9, 2005.

Moernaut, J., Verschuren, D., Charlet, F., Kristen, I., Fagot, M., and De Batist, M.: The seismic-stratigraphic record of lake-level fluctuations in Lake Challa: Hydrological stability, and change in equatorial East Africa over the last $140 \mathrm{ka}$, Earth Planet. Sc. Lett., 290, 214-223, https://doi.org/10.1016/j.epsl.2009.12.023, 2010.

Munroe, J. and Brencher, Q.: Holocene Carbon Burial in Lakes of the Uinta Mountains, Utah, USA, quaternary, 2, 1-13, https://doi.org/10.3390/quat2010013, 2019.

Naeher, S., Gilli, A., North, R. P., Hamann, Y., and Schubert, C. J.: Tracing bottom water oxygenation with sedimentary $\mathrm{Mn} / \mathrm{Fe}$ ratios in Lake Zurich, Switzerland, Chem. Geol., 352, 125-133, https://doi.org/10.1016/j.chemgeo.2013.06.006, 2013.

Nolan, M. and Brigham-Grette, J.: Basic hydrology, limnology, and meteorology of modern Lake El'gygytgyn, Siberia, J. Paleolimnol., 37, 17-35, https://doi.org/10.1007/s10933-006-9020-y, 2007

Nolan, M., Liston, G., Prokein, P., Brigham-Grette, J., Sharpton, V. L., and Huntzinger, R.: Analysis of lake ice dynamics, and morphology on Lake El'gygytgyn, NE Siberia, using synthetic aperture radar (SAR), and Landsat, J. Geophys. Res., 107, 8162, https://doi.org/10.1029/2001JD000934, 2002.

Nowaczyk, N. R., Melles, M., and Minyuk, P.: A revised age model for core PG1351 from Lake El'gygytgyn, Chukotka, based on magnetic susceptibility variations tuned to northern hemisphere insolation variations, J. Paleolimnol., 37, 65-76, https://doi.org/10.1007/s10933-006-9023-8, 2007.

Oswald, W. W., Anderson, P. M., Brown, T. A., Brubaker, L. B., Hu, F. S., Lozhkin, A. V., Tinner, W., and Kaltenrieder, P.: Effects of sample mass, and macrofossil type on radiocarbon dating of arctic, and boreal lake sediments, Holocene, 15, 758-767, 2005.

Pajunen, H.: lake sediments: their carbon store, and related accumulations rates, Spec. Pap. Geol. Surv. Finl., 29, 39-69, 2000.

Pfalz, P., Diekmann, B., Freytag, J.-C., and Biskaborn, B. K.: Harmonizing heterogeneous multi-proxy data from lake systems, Comput. Geosci., 153, 104791, https://doi.org/10.1016/j.cageo.2021.104791, 2021.

Pokorný, M., Sanderson, D., Cresswell, A., Manuel Lirio, J., Herminda Coria, S., Nedbalová, L., Lami, A., Musazzi, S., Van de Vijver, B., Nývlt, D., and Kopalová, K.: Late-Holocene palaeoenvironmental changes at Lake Esmeralda (Vega Island, Antarctic Peninsula) based on a multi-proxy analysis of laminated lake sediment, Holocene, 29, 1155-1175, https://doi.org/10.1177/0959683619838033, 2019.

Procházka, V., Mizera, J., Kletetschka, G., and Vondrák, D.: Late Glacial sediments of the Stará Jímka paleolake, and the first finding of Laacher See Tephra in the Czech Republic, Int. J. Earth Sci., 108, 357-378, https://doi.org/10.1007/s00531-018-1658-y, 2019.

R Core Team.: R: A language, and environment for statistical computing, R Foundation for Statistical Computing, Vienna, Austria, available at: http://www.R-project.org/ (last access: 19 August 2021), 2013.

Regnéll, C., Haflidason, H., Mangerud, J., and Svendsen, J. I.: Glacial and climate history of the last 24000 years in the Polar Ural Mountains, Arctic Russia, inferred from partly varved lake sediments, Boreas, 48, 432-443, https://doi.org/10.1111/bor.12369, 2019.

Reimer, P. J., Austin, W. E. N., Bard, E., Bayliss, A., Blackwell, P. G., Bronk Ramsey, C., Butzin, M., Cheng, H., Edwards, R. L., Friedrich, M., Grootes, P. M., Guilderson, T. P., Hajdas, I., Heaton, T. J., Hogg, A. G., Hughen, K. A., Kromer, B., Manning, S. W., Muscheler, R., Palmer, J. G., Pearson, C., van der Plicht, J., Reimer, R. W., Richards, D. A., Scott, E. M., Southon, J. R., Turney, C. S. M., Wacker, L., Adolphi, F., Büntgen, U., Capano, M., Fahrni, S. M., Fogtmann-Schulz, A., Friedrich, R., Köhler, P., Kudsk, S., Miyake, F., Olsen, J., Reinig, F., Sakamoto, M., Sookdeo, A., and Talamo, S.: The IntCal20 Northern Hemisphere Radiocarbon Age Calibration Curve (0-55 cal ka BP), Radiocarbon, 62, 725-757, https://doi.org/10.1017/RDC.2020.41, 2020.

Schirrmeister, L., Grosse, G., Wetterich, S., Overduin, P. P., Strauss, J., Schuur, E. A. G., and Hubberten, H. W.: Fossil Organic Matter Characteristics in Permafrost Deposits of the Northeast Siberian Arctic, J. Geophys. Res., 116, G00M02, https://doi.org/10.1029/2011JG001647, 2011.

Sekellick, A., Banks, W., and Myers, M.: Water Volume, and Sediment Volume, and Density in Lake Linganore between Boyers Mill Road Bridge, and Bens Branch, Frederick County, Mary- 
land. Scientific Investigations Report, 2013-5082, U.S. Department of the Interior, U.S. Geological Survey, 2013.

Shevtsova, I., Heim, B., Kruse, S., Schröder, J., Troeva, E.I., Pestryakova, L. A., Zakharov E. S., and Herzschuh, U.: Strong shrub expansion in tundra-taiga, tree infilling in taiga, and stable tundra in central Chukotka (north-eastern Siberia) between 2000, and 2017, Environ. Res. Lett., 15, 8, https://doi.org/10.1088/1748-9326/ab9059, 2020.

Sifeddine, A., Meyers, P., Cordeiro, R., Albuquerque, A., Bernardes, M., Turcq, B., and Abra o, J.: Delivery, and deposition of organic matter in surface sediments of Lagoa do Caçó (Brazil), J. Paleolimnol., 45, 385-396, https://doi.org/10.1007/s10933-011-9506-0, 2011.

Singh, M., Sinha, R., and Tandon, S. K.: Geomorphic connectivity, and its application for understanding landscape complexities: a focus on the hydro-geomorphic systems of India, Earth Surf. Process. Landf., 46, 110-130, 2020.

Smith, D. and Jol, H.: Radar structure of a Gilbert-type delta, Peyto Lake, Banff National Park, Canada, Sediment. Geol., 113, 195209, https://doi.org/10.1016/S0037-0738(97)00061-4, 1997.

Smol, J. P., Birks, H. J. B., and Last, W. M. (Eds.): Tracking environmental change using lake sediments, Kluwer academic publishers, New York, USA, 2002.

Sobek, S., Durisch-Kaiser, E., Zurbrügg, R., Wongfun, N., Wessels, M., Pasche, N., and Wehrli, B.: Organic carbon burial efficiency in lake sediments controlled by oxygen exposure time, and sediment source, Limnol. Oceanogr., 54, 2243-2254, https://doi.org/10.4319/lo.2009.54.6.2243, 2009.

Sobek, S., Anderson, N. J., Bernasconi, S. M., and Sontro T. D.: Low organic carbon burial efficiency in arctic lake sediments, J. Geophys. Res.-Biogeo., 119, 1231-1243, https://doi.org/10.1002/2014JG002612, 2014.

Stauch, G. and Gualtieri, L.: Late Quaternary glaciations in northeastern Russia, J. Quaternary Sci., 23, 545-558, https://doi.org/10.1002/jqs.1211, 2008.

Stauch, G. and Lehmkuhl, F.: Quaternary glaciations in the Verkhoyansk Mountains, Northeast Siberia, Quaternary Res., 74, 145-155, https://doi.org/10.1016/j.yqres.2010.04.003, 2010.

Strauss, J., Schirrmeister, L., Grosse, G., Wetterich, S., U1rich, M., Herzschuh, U., and Hubberten, H.-W.: The deep permafrost carbon pool of the Yedoma region in Siberia, and Alaska, Geophys. Res. Lett., 40, 6165-6170, https://doi.org/10.1002/2013GL058088, 2013.

Strunk, A., Olsen, J., Sanei, H., Rudra, A., and Larsen, N.: Improving the reliability of bulk sediment radiocarbon dating, Quaternary Sci. Rev., 242, 106442, https://doi.org/10.1016/j.quascirev.2020.106442, 2020.

Stuiver, M., Reimer, P. J., and Reimer, R. W.: CALIB 8.2, available at: http://calib.org (last access: 17 August 2021), 2020.

Subetto, D. A., Nazarova, L. B., Pestryakova, L. A., Syrykh, L. S., Andronikov, A. V., Biskaborn, B., Diekmann, B., Kuznetsov, D. D., Sapelko, T. V., and Grekov, I. M.: Paleolimnological studies in Russian northern Eurasia: A review, Contemp. Probl. Ecol., 10, 327-335, 2017.
Tranvik, L. J., Downing, J. A., Cotner, J. B., Loiselle, S. A., Striegl, R. G., Ballatore, T. J., Dillon, P., Finlay, K., Fortino, K., Knoll, L. B., Kortelainen, P. L., Kutser, T., Larsen, S., Laurion, I., Leech, D. M., McCallister, S. L., McKnight, D. M., Melack, J. M., Overholt, E., Porter, J. A., Prairie, Y., Renwick, W. H., Roland, F., Sherman, B. S., Schindler, D. W., Sobek, S., Tremblay, A., Vanni, M. J., Verschoor, A. M., von Wachenfeldt, E., and Weyhenmeyer, G. A.: Lakes and reservoirs as regulators of carbon cycling, and climate, Limnol. Oceanogr., 54, 2298-2314, https://doi.org/10.4319/lo.2009.54.6_part_2.2298, 2009.

Tripathi, J. and Rajamani, V.: Geochemistry of the loessic sediments on Delhi ridge, eastern Thar Desert, Rajasthan: implications for exogenic processes, Chem. Geol., 155, 265-278, https://doi.org/10.1016/S0009-2541(98)00168-5, 1999.

Van der Bilt, W., Bakke, J., Vasskog, K., D' Andrea, W. J., Bradley, R. S., and Ólafsdóttir, S.: Reconstruction of glacier variability from lake sediments reveals dynamic Holocene climate in Svalbard, Quaternary Sci. Rev., 126, 15, 201-218, https://doi.org/10.1016/j.quascirev.2015.09.003, 2015.

Vologina, E. G., Granin, N. G., Lomonosova, T. K., Vorobyeva, S. S., Kulikova, N. A., Kalashnikova, I. A., and Granina, L. Z.: Input of silt-sand material to the central part of southern lake Baikal by ice transportation, BAIK-SED-2, Gent University, Belgium, 17-18, 2003.

Vyse, S. A., Herzschuh, U., Andreev, A. A., Pestryakova, L. A., Diekmann, B., Armitage, S. J., and Biskaborn, B. K.: Geochemical, and sedimentological responses of arctic glacial Lake Ilirney, chukotka (far east Russia) to palaeoenvironmental change since $\sim 51.8 \mathrm{ka} \mathrm{BP}$, Quaternary Sci. Rev., 247, 106607, https://doi.org/10.1016/j.quascirev.2020.106607, 2020.

Vyse, S. A., Herzschuh, U., Pfalz, G., Diekmann, B., Nowaczyk, N. R., Pestryakova, L. A., and Biskaborn, B. K.: Sedimentological and biogeochemical dataset for Arctic glacial lake Rauchuagytgyn, Chukotka, Russia, PANGAEA [data set], https://doi.org/10.1594/PANGAEA.929719, 2021.

Wang, R., Zhang, Y., Wuennemann, B., Biskaborn, B. K., Yin, H., Xia, F., Zhou, L., and Diekmann, B.: Linkages between Quaternary climate change, and sedimentary processes in Hala Lake, northern Tibetan Plateau, China. J. Asian Earth Sci., 107, 140 150, 2015.

Windirsch, T., Grosse, G., Ulrich, M., Schirrmeister, L., Fedorov, A., Konstantinov, P., Fuchs, M., Jongejans, L., Wolter, J., Opel, T., and Strauss, J.: Organic carbon characteristics in ice-rich permafrost in alas, and Yedoma deposits, central Yakutia, Siberia, Biogeosciences, 17, 3797-3814, https://doi.org/10.5194/bg-173797-2020, 2020.

Woolway, R. I. and Merchant, C. J.: Worldwide alteration of lake mixing regimes in response to climate change, Nat. Geosci., 12, 271-276, https://doi.org/10.1038/s41561-019-0322-x, 2019.

Zhuravlev, G. F., Kazymin, S. S., and Pukalo, P. V.: State geological map of the Russian Federation, scale $1: 200000$, AnjuyjskerChaunsker Series, Moscow, St. Petersburg, 1999. 